\title{
The interplay of circulating tumor DNA and chromatin modification, therapeutic resistance, and metastasis
}

\author{
Lei Zhang ${ }^{1,2,3 \dagger}$, Yiyi Liang ${ }^{1,2,3 \dagger}$, Shifu Li ${ }^{1,2,3 \dagger}{ }^{4}$, Fanyuan Zeng ${ }^{1,2,3 \dagger}$, Yongan Meng ${ }^{1,2,3 \dagger}$, Ziwei Chen ${ }^{1,2,3}$, Shuang Liu ${ }^{3}$, \\ Yongguang $\mathrm{TaO}^{1,2,3,4^{*}}$ (D) and Fenglei $\mathrm{Yu}^{4^{*}}$
}

\begin{abstract}
Peripheral circulating free DNA (cfDNA) is DNA that is detected in plasma or serum fluid with a cell-free status. For cancer patients, cfDNA not only originates from apoptotic cells but also from necrotic tumor cells and disseminated tumor cells that have escaped into the blood during epithelial-mesenchymal transition. Additionally, cfDNA derived from tumors, also known as circulating tumor DNA (ctDNA), carries tumor-associated genetic and epigenetic changes in cancer patients, which makes ctDNA a potential biomarker for the early diagnosis of tumors, monitory and therapeutic evaluations, and prognostic assessments, among others, for various kinds of cancer. Moreover, analyses of cfDNA chromatin modifications can reflect the heterogeneity of tumors and have potential for predicting tumor drug resistance.
\end{abstract}

Keywords: ctDNA, Chromatin modification, Therapeutic resistance, Metastasis, Tumor heterogeneity

\section{Biological features of ctDNA}

Peripheral circulating free DNA is DNA that is detected in plasma or serum fluid with a cell-free status. It may originate from apoptosis or necrosis. The amount of circulating DNA in healthy people is minimal. However, when the body is afflicted by tumors, autoimmune disease, and inflammatory reactions, the amount of circulating free DNA in the body can increase in correlation to different disease statuses [1]. Circulating free DNA is often a double-stranded DNA fragment that exists in the form of a protein complex [2]. The size of the cfDNA varies, with a length ranging from $18 \mathrm{bp}$ to $10000 \mathrm{bp}$. Among cfDNAs, circulating tumor DNA (ctDNA), which is believed to come from tumor cells, has attracted significant interest from researchers. Nucleosomes released together with ctDNA, acting as carriers,

\footnotetext{
* Correspondence: taoyong@csu.edu.cn; yufenglei@csu.edu.cn Lei Zhang, Yiyi Liang, Shifu Li, Fanyuan Zeng, Yongan Meng are equal contributors.

${ }^{1}$ Key Laboratory of Carcinogenesis and Cancer Invasion, Ministry of Education, Department of Pathology, Xiangya Hospital, Central South University, 87 Xiangya Road, Changsha 410008, Hunan, China

${ }^{4}$ Department of Thoracic Surgery, Second Xiangya Hospital, Central South

University, Changsha 410011, China

Full list of author information is available at the end of the article
}

enter the blood in single, double or triple forms, and thus most ctDNA shows significant fragmentary characteristics. Moreover, the half-life of ctDNA in the blood circulation is less than 2 hours [3]. Additionally, tumor-specific changes (changes in DNA integrity [4], mutations in oncogenes or tumor suppressor genes [5], gene methylation abnormalities, microsatellite alterations [6], changes in mitochondrial DNA load levels [7], chromosomal genomes rearrangements, etc.[5]) can be detected in the ctDNA of cancer patients. In summary, ctDNA is not only easy to identify, but its blood concentration can also reflect the latest developments and specificity of tumors in real time [8]. The applications of ctDNA include the followings: (1) identifying mutations of interest, including mutations responsible for resistance to therapy, in ctDNA; (2) early detection of disease recurrence in minimal residual diseases; (3) early detection of primary disease; (4) identification of genetic determinants for targeted therapy; (5) serial ctDNA quantification to assess tumor burden; (6) reflection of the metabolic biology of tumors. (Fig. 1)

(C) The Author(s). 2019 Open Access This article is distributed under the terms of the Creative Commons Attribution 4.0 International License (http://creativecommons.org/licenses/by/4.0/), which permits unrestricted use, distribution, and reproduction in any medium, provided you give appropriate credit to the original author(s) and the source, provide a link to the Creative Commons license, and indicate if changes were made. The Creative Commons Public Domain Dedication waiver (http://creativecommons.org/publicdomain/zero/1.0/) applies to the data made available in this article, unless otherwise stated. 

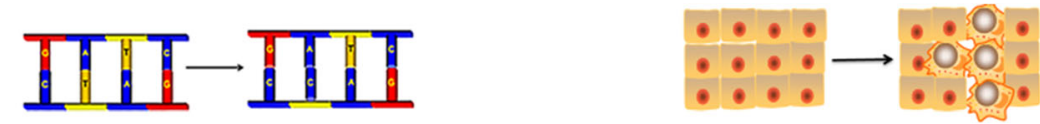

1. Identifying mutations of interest

2. Early detection of recurrence

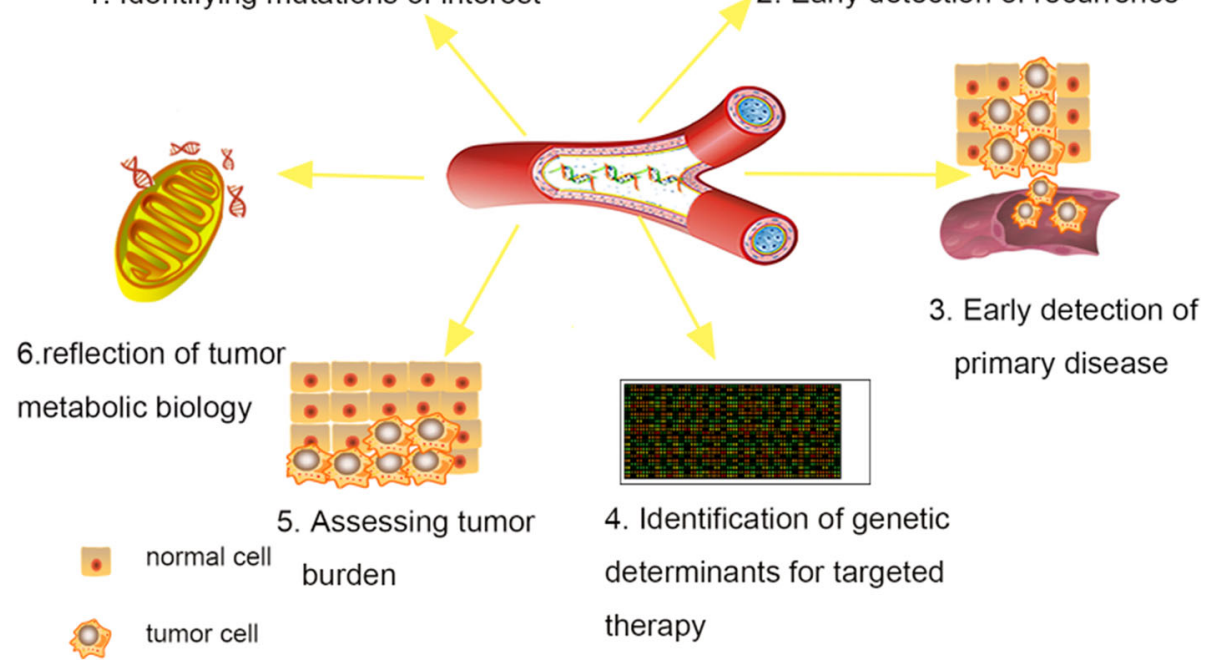

Fig. 1 The clinic applications of ctDNA include (1) ctDNA to identify mutations of interest (including resistance mutations), (2) early detection of disease recurrence in minimal residual disease, and (3) early detection of primary disease. (4) Identification of genetic determinants for targeted therapy. (5) Serial ctDNA quantification to assess tumor burden. (6) Reflection of tumor metabolic biology

\section{Origin and test methods for ctDNA Origin of ctDNA}

In healthy human plasma, cfDNA mainly derives from apoptotic cells [9]. In addition, all living cells spontaneously release DNA fragments, which are called metabolic DNA fragments, into the blood. Metabolic DNA fragments have practical biological functions, such as acting as transcriptional templates of RNA and binding to glycoproteins as messengers. However, cfDNA can originate from necrotic and apoptotic tumor cells [10]; exosomes derived fromcancer cells [11, 12]; disseminated tumor cells (DTC), which may intravasate from a solid tumor and travel through the blood stream and subsequently extravasate into distant organs, such as the bone marrow [13]; and circulating tumor cells (CTCs), which are tumor cells that have, presumably, been released or passively shed from the primary tumor and/or metastatic lesions into the bloodstream [14-17] in cancer patients.

The amount of ctDNA in a patients' blood is closely correlated with tumor burden and increases significantly with tumor growth [9]. If a patient carries a tumor weighing approximately $100 \mathrm{~g}$ (equivalent to $3 \times 10^{10}$ cells), 3.3\% of the tumor-derived DNA will be released into the blood each day given that a single human somatic cell contains approximately 6.6 pg of genomic DNA [18]. A study based on cfDNA analysis of 45 breast cancer patients, 42 colorectal cancer patients, 65 lung cancer patients, 42 ovarian cancer patients and 44 healthy people showed that cancer patients present elevated cfDNA level of $29 \mathrm{ng} / \mathrm{ml}$ compared with $7 \mathrm{ng} / \mathrm{ml}$ of healthy people.[19] Size, status, and characteristics of cancerous tissues are also highly related. For example, when considering intratumor heterogeneity, subclones carrying driver mutations are more prone to release DNA [20]. However, some researches [21] in non-small cell lung cancer (NSCLC) have indicated that the cfDNA level is correlated with tumor metabolism and reflects tumor biological behaviors rather than tumor burden, potentially because nontumor DNA is also increased during tumor progression due to interactions between tumor cells and adjacent healthy tissue cells [22].

The earliest attempt to analyze ctDNA, however, date to the 1950s. Mandel [23] detected floating DNA fragments (cell-free DNA, cfDNA) in normal blood in 1948; however, their first driving work did not receive sufficient attention. In 1977 [24], it was evident that the content of DNA in the blood of tumor patients was significantly higher than that in healthy individuals, especially in advanced tumor patients. However, it was not until 1989 that researchers discovered the presence of fragments of cfDNA in the plasma and serum of cancer patients with the same genetic changes as the tumor [25]. Mutated K-ras sequences were identified in plasma 
DNA from three patients with pancreatic carcinoma in 1994 [26], and in the same year, point mutations of the $\mathrm{N}$-Ras gene were also demonstrated in the plasma DNA of patients with myelodysplastic syndrome or acute myelogenous leukemia [27]. Since then, the concept of 'liquid biopsy' was born. Microsatellite analysis of serum as a novel method detected the microsatellite alterations of circulating tumor cell DNA of small cell lung cancer patients [28] and head and neck cancer patients in 1996 [6]. Three years later, in 1999, aberrant promoter hypermethylation of cancer-related genes in serum was detected by methylation-specific PCR, which may be useful for cancer diagnosis or the detection of recurrence [29] (Fig. 2).

Although extensive researches had been performed, such studies remained to be validated in clinical practice. The clinical evaluation of ctDNA alterations was first proposed in 2005 [18]. Subsequently, ctDNA measurements were used to responsibly monitor the dynamics of tumor burden [30] and analyze acquired resistance to cancer treatments [31, 32]. In a comprehensive study in 2014, the clinical validation of ctDNA analysis in oncology was first proposed [33]. Moreover, DNA from serum or blood provided another clinic domain: fetus-derived $Y$ sequences were detected in pregnant women's blood in 1997, which indicated that fetal DNA could enter the blood [34]. Thus, a noninvasive prenatal diagnosis became possible. cfDNA researches later focused more attention on cancer research rather than prenatal diagnosis, potentially because detecting tumor DNA is much more difficult than fetal DNA due to early, inaccurate sequencing technologies.

\section{Test methods for ctDNA}

The first step in detecting cfDNA is to extract free DNA from the peripheral blood within 4-5 hours after drawing
$1 \mathrm{ml}$ serum or plasma. Taking lung cancer as an example, there are many detection methods for single gene mutations (such as epidermal growth factor receptor (EGFR) mutations) in cfDNA, such as liquid chromatography, the mutation amplification block method, digital PCR, and second-generation sequencing. Overall, the BEAMing digital PCR method is the most sensitive approach, providing a sensitivity reaching $0.01 \%$ in comparison to that of other methods of approximately $1 \%$. The four methods used to detect ctDNA EGFR mutations comprise two amplification refractory mutation systems (cobas-ARMS and ADx-ARMS), a droplet digital polymerase chain reaction (ddPCR) and next-generation sequencing (Firefly NGS) platform. Firefly NGS, cobas-ARMS and ddPCR are more sensitive than ADx-ARMS, while ADx-ARMS is suitable for the quantitative detection of EGFR mutations with an allele frequency greater than 1\% [35]. However, ctDNA sequencing methods, such as NGS, still sometimes cannot reflect all the somatic mutations in biopsy tissue [36], and thus a detection approach with high sensitivity is anticipated (Table 1).

The detection of ctDNA in background cfDNA released from normal human cells is one of the challenges faced by current ctDNA assays. ctDNA fragments are shorter than plasma background cfDNA fragments, as confirmed in rat brain glioblastoma, rat hepatoma, human melanoma [37], lung cancer [38] and metastatic colorectal carcinoma [9]. Moreover, researches in hepatoma, melanoma and lung cancer [38] also support the increased accumulation of short cfDNA during tumor-related alterations. Thus, the isolation of a set of cfDNA fragments of a specific length by experimental or bioinformatics improvement may increase the detection rate of ctDNA.

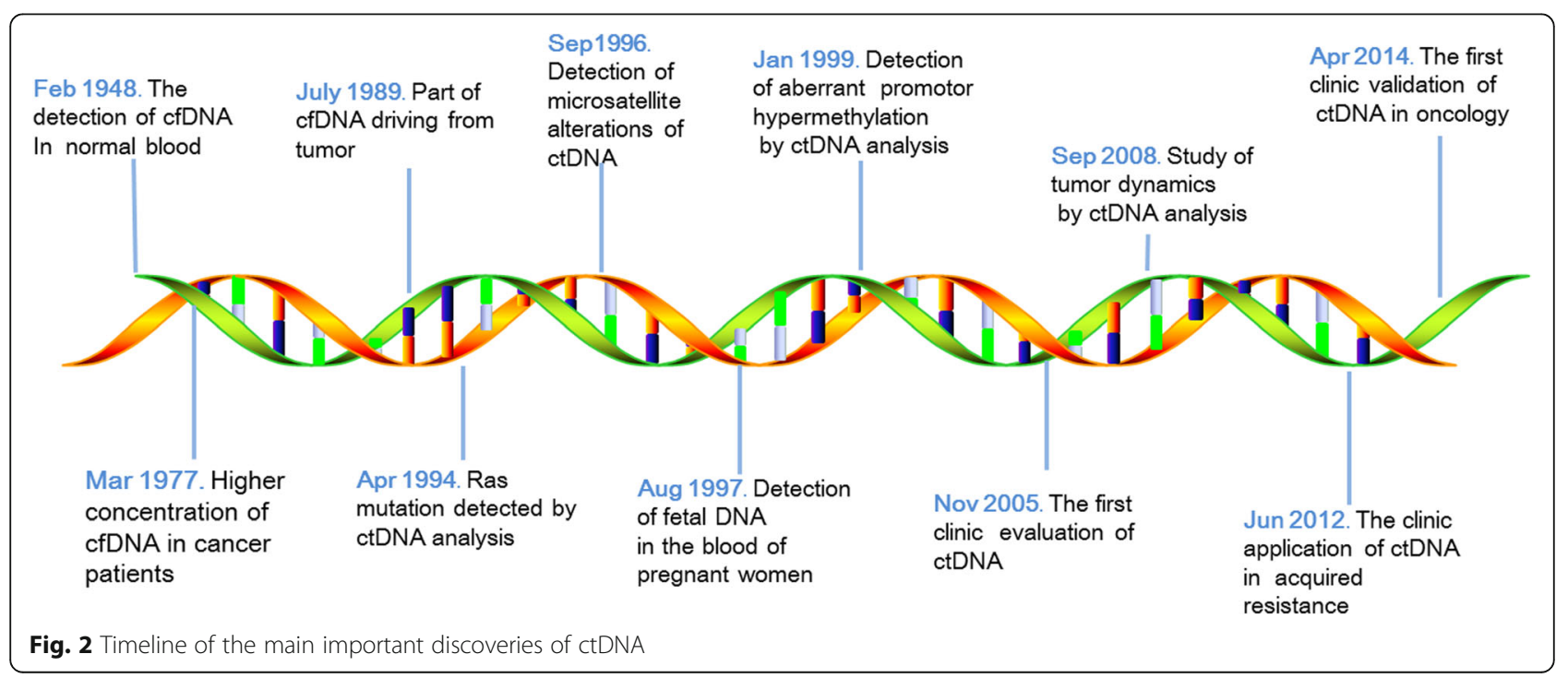


Table 1 Common ctDNA Analysis Techniques. Description of Twelve Common Methodologies of ctDNA Analysis

\begin{tabular}{|c|c|}
\hline Technique & Main features \\
\hline $\begin{array}{l}\text { Hybrid-capture- } \\
\text { based Liquid } \\
\text { Biopsy } \\
\text { Sequencing (LB- } \\
\text { Seq) }\end{array}$ & $\begin{array}{l}\text { A hybridization-based } \\
\text { method sequencing all } \\
\text { protein-coding exons }\end{array}$ \\
\hline $\begin{array}{l}\text { DNA clutch } \\
\text { probes (DCP) }\end{array}$ & $\begin{array}{l}\text { Without enzymatic } \\
\text { amplification but a DCP } \\
\text { used to prevents the } \\
\text { reassociation of ssDNAs }\end{array}$ \\
\hline $\begin{array}{l}\text { iDES-enhanced } \\
\text { CAPP-Seq }\end{array}$ & $\begin{array}{l}\text { Combining in silico } \\
\text { elimination of highly } \\
\text { stereotypical } \\
\text { background artifacts } \\
\text { with a molecular } \\
\text { barcoding strategy for } \\
\text { the efficient recovery of } \\
\text { cfDNA molecules }\end{array}$ \\
\hline
\end{tabular}

Targeted error A direct evaluation of correction sequencing (TEC-Seq)
Nanoplasmonic biosensor
Simple multiplexed PCR-based barcoding of DNA sequence changes in circulating cell-free DNA using massively parallel sequencing

Description
Barcoded cfDNA-seq li-
braries design, probe
hybridization, target cap-
ture, post-capture ampli-
fication and bead clean
up of captured amplified
DNA

ctDNA denaturization, DCP preventing reassociation of ssDNA, PNA clamps hybridizing to the matched wild type, detection of remaining singlestranded mutant target ctDNA

Designing 'index' barcode and'insert' barcodes, PCR, mapping to reference genome to recover single strand, duplex recovery, in silico reassembly of original DNA duplex

including dual-index barcode adapters design, cfDNA library formation, redundant sequencing ation of duplicate fragments, alignment to the reference genome, identification of bona fide alterations.

A change of the refractive index surrounding the biosensor surface for binding of ctDNA to the

PNA-probed AuNP surface. Change of Rl as distinct LSPR-peak changes on the Rayleigh light scattering. Detection and amplification of methylation by specifically binding immunogold colloids

Detection of extremely rare variant alleles within a complex mixture of DNA molecules

Comprising a three-cycle barcoding PCR step followed directly by adaptor PCR to generate the library and then of the library, reconcili-

Accuracy, sensitivity, Advantages

specificity

AFs: $0.25 \%$

specificity: $98 \%$

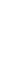

\section{Detect $0.01 \%$ mutations}

4 in 105 cfDNA molecules specificity $>99.9999 \%$ specific detection of low-abundance sequence alterations using NGS

1. High fidelity
2. Screening for
mutations throughout
a diversity of genomic
regions

1. High specificity with less time requirement 2. Chip-based format supports automation.

Increased scalability, flexibility, coverage uniformity, and ability to reliably assess all mutation classes in a single assay bead purification before sequencing

Digital approaches involve the counting of methylated and unmethylated fragments, one-by-one, thereby dramatically increasing the signalto-noise ratio of the assay.

1.Simplicity of the NGS

cohorts for
standardized clinical
interpretations

Sensitive digital Providing an quantification of opportunity to assess methylation in allele-specific PCR, reclinical samples striction digestion or specific hybridization probes
Error correction to $<0.1 \%$,

the methylated

DNA fraction was $0.018 \%$
Sensitivity: fou
times ( $50 \mathrm{fM})$
improvement

Simultaneous detection of the hot-spot mutation and epigenetic changes on the ctDNA library construction protocol and the ease in any reasonably capable research laboratory

2. The low DNA input $(<5 \mathrm{ng})$,

1.enabling increased sensitivity and specificity 2.enabling comparisons across different patient cohorts for standardized clinical interpretations
Challenges or Ref.

perspectives

Larger portions of the

[39] genome to query other target genes or mutation classes like rearrangements and copy number alterations

Monitoring diseases caused by DNA viruses

Allowing for greater analytical sensitivity than iDES if > 200 somatic mutations were targeted

Sensitivity may be further improved by deeper sequencing, improved error correction methods, larger blood volumes, and repeated testing at regular intervals.

Providing sharp

sensitive and multiplexed platform for detecting other associated biomarkers and their modifications at low concentration.

1. time-consuming, and not be the best approach for coverage of consistent, large target regions on many samples.

2. Requirement of deep sequencing, and sequencing costs 
Table 1 Common ctDNA Analysis Techniques. Description of Twelve Common Methodologies of ctDNA Analysis (Continued)

\begin{tabular}{|c|c|c|c|c|c|c|}
\hline Technique & Main features & Description & $\begin{array}{l}\text { Accuracy, sensitivity, } \\
\text { specificity }\end{array}$ & Advantages & $\begin{array}{l}\text { Challenges or } \\
\text { perspectives }\end{array}$ & Ref. \\
\hline $\begin{array}{l}\text { Nanostructured } \\
\text { conductive } \\
\text { polymer } \\
\text { platform }\end{array}$ & $\begin{array}{l}\text { Extracting tumor-specific } \\
\text { circulating cfDNA from } \\
\text { unprocessed plasma } \\
\text { using an electroactive } \\
\text { Ppy/Au NW platform }\end{array}$ & $\begin{array}{l}\text { Ppy-coated Au } \\
\text { nanowires (Ppy/Au NWs) } \\
\text { capture DNA with } \\
\text { oxidation electric fields } \\
\text { by DNA-Ppy surface ad- } \\
\text { sorption, while Ppy/Au } \\
\text { NWs release DNA with } \\
\text { reduction electric fields. }\end{array}$ & $\begin{array}{l}\text { mean purity: } 1.97 \pm \\
0.02\end{array}$ & $\begin{array}{l}\text { Enhanced efficiency, } \\
\text { high yield and high } \\
\text { purity }\end{array}$ & - & {$[45]$} \\
\hline $\begin{array}{l}\text { Tagged- } \\
\text { amplicon deep } \\
\text { sequencing } \\
\text { (TAm-Seq) }\end{array}$ & $\begin{array}{l}\text { Combining short } \\
\text { amplicons, two-step } \\
\text { amplification, sample } \\
\text { barcodes with high- } \\
\text { throughput PCR }\end{array}$ & $\begin{array}{l}\text { Preamplification of DNA } \\
\text { molecules with or } \\
\text { without mutations, } \\
\text { single-plex PCR to select } \\
\text { region of interest, bar- } \\
\text { coding PCR to harvest } \\
\text { amplicons duplicate se- } \\
\text { quencing to avoid false } \\
\text { positives caused by PCR }\end{array}$ & AF: $2 \%$ & $\begin{array}{l}\text { 1. A balance between } \\
\text { sensitivity and ease of } \\
\text { use } \\
\text { 2. Effective } \\
\text { amplification } \\
\text { 3. Sample barcodes } \\
\text { and high-throughput } \\
\text { PCR } \\
\text { 4. less time }\end{array}$ & $\begin{array}{l}\text { Challenge: detection } \\
\text { limit compared to } \\
\text { assays that target } \\
\text { individual loci }\end{array}$ & [46] \\
\hline
\end{tabular}

$\begin{array}{ll}\text { Single copy } & \text { Schematic } \\ \text { sensitive } & \text { representation of the } \\ \text { electrochemical } & \text { SEDA strategy. } \\ \text { Assay } & \end{array}$

Improved hMeSeal

Discrimination of Rare EpiAlleles by

Melt ( DREAMing )

\section{Determining the} genome-wide distribution of 5 -hmC by selective labeling as enrichment strategy errors

Integrated by dual sequence discrimination processes including methylation-specific annealing and specific interface hybridization, as well as cascade signal amplification processes represented by the asymmetric MSP and HRP catalytic reaction.

\section{Using the T4}

bacteriophage beta-

glucosyltransferase to install a glucose moiety with an azide group onto the hydroxyl group of 5-hmC. then labeled with biotin, thus enables 5-hmC-containing DNA detection, capture, enrichment and sequencing

cfDNA extraction, bisulite conversion, sample dilution, PCR amplification and derivative melt profile analysis. Melt profile shows a secondary melt peak for fully methylated and heterogeneouslymethylated epiallele while melt curve of the unmethylated presents only one peak.
The high specificity 1 . Integrated by dual reaching a $0.1 \%$ sequence methylation index discrimination processes and cascade signalamplification processes 2. Detection of tumor related methylation in lung cancer patients with 200 microlitre plasma samples.

\section{Detection limit: Providing acurate and} $\sim 0.004 \%$ comprehensive capture of 5-hmC-containing DNA fragments, while still providing high selectivity.
Enable us to understand the role(s) of the 5 -hmC modification at molecular, cellular and physiological levels.

\section{Single-CpG-site 1.Minimal time and} resolution in fractions: $0.005 \%$

1.Minimal time and qPCR machine and microtiter plate. 2.'DREAM analysis' histogram helps easily visualize epigenetic/ epiallelic heterogeneity.
1. The sensitivity of the assay determined by the dominant epiallelic methylation density, and epiallelic species not be accurately represented.

2. Relatively low throughput.

3. Not directly provide sequence information.

Description of Twelve Common Methodologies of ctDNA Analysis. These developed assays and protocols enable excellent accuracy, sensitivity and specificity in the detection of ctDNA and its variation. And those approaches have their own advantages and perspectives. Those approaches include hybrid-capture-based Liquid Biopsy Sequencing (LB-Seq), DNA clutch probes (DCP), integrated digital error suppression (iDES)-enhanced CAPP-Seq, targeted error correction sequencing (TEC-Seq), nanoplasmic biosensor, Simple multiplexed PCR-based barcoding of DNA, Sensitive digital quantification of DNA methylation, Nanostructured conductive polymer platform, tagged-amplicon deep sequencing (TAm-Seq), Single copy sensitive electrochemical assay, Improved hMe-Seal and Discrimination of Rare EpiAlleles by Melt (DREAMing). (AF: allele frequencies)

Newly developed assays and protocols enable excellent sensitivity and specificity in the detection of ctDNA and its variations, including hybrid-capture-based liquid biopsy sequencing (LB-Seq) [39], which is a strategy that relies on the use of DNA clutch probes (DCP) [40]; integrated digital error suppression (iDES)-enhanced 
CAPP-Seq [41]; targeted error correction sequencing (TEC-Seq) [19]; nanoplasmic biosensors [42]; SiMSen-seq [43]; methyl-BEAMing [44]; electroactive conducting polymer nanowire platforms [45]; tagged-amplicon deep sequencing (TAm-Seq) [46]; , cMethDNA [47]; and single-copy sensitive electrochemical assays [48]. Methods for determining the genome-wide distribution of 5-hmC (hMe-Seal) $[49,50]$ and intratumoral epigenetic heterogeneity (DREAMing) [51] by lipid biopsy have also been reported.

Furthermore, using ichorCNA [52], a statistical software, the ctDNA content in cfDNA samples can be assessed to identify if the samples meet the criteria for the full exon sequencing. This method can be used to screen cfDNA samples and identify those that qualify for cfDNA exon sequencing, thus having the potential for use in clinical work. In general, the ultimate aim of ctDNA analysis is to detect early cancers in asymptomatic patients [53]. Despite the aforementioned advantages of cfDNA test methods, their sensitivity and specificity can be undermined by certain challenges. The most striking challenge is the presence of shared mutations between different tumor types, such as KRAS and the EGFR gene, making it difficult to correlate a cancer to a specific organ [53,54]. However, the exact limitations may vary with the types of tests taken, as listed in the table.

\section{The caveats and technical issues associated with ctDNA as a biomarker}

Since examinations of ctDNA can be performed in a simple and noninvasive manner, this technique has the potential to replace invasive biopsies for patients with insufficient tissue in the first line and progression [55, 56]. A huge advantage of liquid biopsies is the ability to conduct longitudinal monitoring of on-treatment patients as a readout of therapeutic efficacy [57]. ctDNA measurements are stable and have the potential to be used in clinical settings. They can be used as a dynamic biomarker of cancer for early detection, diagnosis and treatment monitoring, and they may also be used to guide patients in choosing adjuvant chemotherapy [58]. However, one of the technical challenges of liquid biopsies is that both healthy and malignant cells release DNA into peripheral blood, thus only a small proportion of cfDNA is tumor-derived ctDNA. In the early stages of cancer, ctDNA levels in cfDNA are lower, making detection more difficult $[41,59]$. In addition, ctDNA must be distinguished from cfDNA that is not associated with tumors, especially in patients who have received radiation and chemotherapy [60]. Moreover, the mechanism of ctDNA release and clearance is poorly understood, and the effect of factors such as tumor location is unknown $[61,62]$ One major concern about liquid biopsies is that mutations of cfDNA in peripheral blood may not be tumor-derived [61]. Therefore, although circulating DNA analysis is promising and convenient, the uniformity of circulating DNA collection and analysis remains insufficient, making the absolute ctDNA amount limited as a diagnostic tool [62].

The purpose of a liquid biopsy is to identify mutations in the target genes and detect emerging resistance to treatment [63]. Therefore, the variation of the ctDNA concentration during treatment appears to be an early biomarker related to therapeutic efficacy. In addition, postoperative ctDNA detection is a marker of residual diseases and a strong indicator predicting the risk of recurrence [64]. In conclusion, the ctDNA level is related to prognosis: a higher ctDNA level is associated with a poorer prognosis. As a result, the ctDNA concentration can be analyzed to change the alternative therapy earlier and minimize side effects $[65,66]$. Beyond directing systemic therapy for advanced disease, ctDNA can also provide predictive therapeutic information. Predictive biomarkers can help identify patients who may respond to or develop resistance to specific therapies [67, 68]. However, ctDNA has not been standardized as a biomarker, which means that the results of the ctDNA analysis may not be comparable due to technological differences [69]. To fully incorporate liquid biopsies into clinical practice, there is a glaring need to standardize methods, such as the way blood samples are collected and stored, the technical specifications of the assays, and ctDNA isolation [58, 63, 70, 71].

Despite recent progresses, there are several important technical challenges to the wider use of ctDNA: insufficient knowledge of the tumor microenvironment and the immunologic response to ctDNA release in liquid biopsy samples; diagnostic tools must be further refined to detect small amounts of tumor-derived components in the circulation; the analytical sensitivity of sequencing methods must be increased [72]. In addition, ctDNA analysis is generally limited to fragments of DNA and requires a priori knowledge of specific DNA aberrations $[60,69]$. With the development of detection technology, a new ctDNA sampling technology is urgently needed to overcome the disadvantages of existing methods, such as high cost, slow speed, low sensitivity, and complexity. (The dimethyl dithiobispropionimidate (DTBP)-based microchannel platform [71] is a good attempt.) Additionally, during the experiment, the sensitivity of the detection method should be reasonably regulated to minimize the probability of a false positive or false negative result $[63,73]$.

The use of ctDNA as biomarkers in clinical practice should meet the following requirements [72]: high analytical validity, combining established prognostic factors with validated prognostic/predictive biomarkers, and 
close evaluation of the accuracy, reliability, and reproducibility of a test [68]. Additionally, sufficient clinical validity (which assesses the ability of a test to divide a population into separate groups with significantly different clinical outcomes) and clinical utility (which evaluates whether changes in adjuvant therapy guided by ctDNA have a positive effect on prognosis [74]) must also be met.

In conclusion, the clinical use of ctDNA as a biomarker requires addressing some challenges, including the development of accurate, targeted, and technically reproducible analysis methods, followed by prospective validation in a large cohort of patients [53].

\section{ctDNA and chromatin modification}

Chromatin modifications comprise DNA modifications and histone modifications. At present, ctDNA-related studies have focused more on DNA methylation. DNA methylation is the conversion of the cytosine of the dinucleotide 5' end of $\mathrm{CpG}$ islands to 5' methyl cytosine (5 $\mathrm{mC}$ ) in a DNA sequence catalyzed by DNA methyltransferase (DNMT). Although DNA methylation, as one of the earliest discovered gene modification methods, does not change gene sequence, it can turn off the activity of certain genes. Demethylation, in contrast, has the opposite effect. Of note, some chromatic remodeling factors, including lymphoid-specific helicase (LSH), have been validated to play pivotal roles in the tumor progression and prognosis of multiple cancers, including gliomas $[75,76]$, lung cancer [77-79] and nasopharyngeal carcinoma [80].

Cells remain normal with high levels of tumor suppressor gene expression. However, if hypermethylation takes place in the CpG islands of tumor suppressor gene promoter regions, which means the tumor suppressor gene is silenced, those cells will break away from the normal cell cycle, thus entering a tumorigenesis process. CpG island hypermethylation in the promoter region of the tumor suppressor gene was first discovered in the retinoblastoma-related $\mathrm{Rb}$ gene, and it is regarded as a common phenomenon in several kinds of tumors, such as non-small cell lung cancer (NSCLC). Hypermethylation has also been seen in cell cycle-regulation-related genes (p16INK4a, p15INK4a, p14ARF, RASSF 1A, etc.) and apoptosis-related genes (DAPK, TMS1, etc.), among others. Of them, some genes including p16, p53, and RASSF 1A show a hypermethylation status in various types of tumor cells, while some other genes only maintain hypermethylation in specific tumor cells [81].

Measurements of gene methylation in plasma DNA enable the early detection of primary cancer and metastases to other organs [82]. Plasma DNA SHOX2 and PTGER4 methylation [83] can differentiate lung cancer, nonmalignant lung diseases and the healthy state.
GADD45a methylation in prostate cancer plasma is apparently higher than in benign prostate tumor plasma [84]. Other circulating methylation markers include SESN3 [82], WIF1, and NPY [85] for localized colorectal cancer, RAS [86], PTK2, WIF1, and NPY [85] for metastatic colorectal cancer, TAC1 [87] promoter for esophageal adenocarcinoma, RASSF1A [81] for thyroid cancer, SEPT9 [88] for hepatocellular carcinoma, and SHOX2 and SEPT9 [89] for head and neck squamous cell carcinomas.

Specific gene methylation detected in circulating DNA before treatment can be a predictive biomarker for anti-cancer therapy efficacy and disease prognosis. Methylation of 14-3-3 [90] could be a predictor of longer survival for NSCLC patients receiving platinum-based chemotherapy. Promoter methylation of O6-methyl-guanine-methyl-transferase (MGMT) [91] could predict glioblastoma and metastatic colorectal cancer patients' response to the alkylating agents dacarbazine or temozolomide. The same phenomenon has been reported for methylated TAC1 [87] promoter DNA for esophageal squamous cell carcinoma, SHOX2 and SEPT9 [89] for head and neck squamous cell carcinomas.

In addition to single gene methylation analysis, the detection of methylated gene panel could also be a promising marker for cancer diagnosis, prognosis and disease monitoring. Studies concerning the methylated gene panel have been reported in metastatic breast cancer [92], lung cancer [83], ovarian cancer [93] and primary non-small cell lung cancer [94].

Some researchers have proposed a new analytical framework based on the methylated haplotype load (MHL), a block-level metric, rather than single-CpG methylation levels [95]. The design demonstrated superior sensitivity over methods using single-CpG methylation levels as features, probably because the detection of MHL could help distinguish blocks with various degrees of coordinated methylation despite same average levels of methylation. Although the accuracy was unsatisfactory due to the lack of valid reference methylomes of pure adult cell types, testing of methylation haplotypes can be regarded as a promising strategy for the development of a cancer-specific signature and tissue-of-origin map, thus hopefully facilitating the early detection of a tumor and its primary site.

The 5-hydroxymethylcytosine $(5 \mathrm{hmC})$ plays a distinct epigenetic role [96], and loss of 5 -hmC has been correlated with cancer metastasis [75]. Research has also shown that 5-hydroxymethylcytosine signatures in cfDNA developed by genome-wide profiling of $5 \mathrm{hmC}$ can distinguish features of specific cancer types and stages and are superior to conventional protein biomarkers and concordant with $5 \mathrm{hmC}$ biomarkers from 
tissue biopsies. This approach has been performed in lung cancer, hepatocellular carcinoma, pancreatic cancer, colorectal cancer and gastric cancer [50, 67, 97, 98].

When a known somatic mutated gene has a low frequency, the epigenome, especially the methylome, can sometimes be analyzed instead to determine specific biomarkers for cancers [99]. Moreover, a study in metastatic colorectal cancer demonstrated that the measurement of NGS together with methylated biomarkers in cfDNA could achieve better accuracy than NGS alone [86].

\section{ctDNA and therapeutic resistance}

According to recent studies in different types of cancer, ctDNA is regarded as an applicable, sensitive, and specific biomarker not only for diagnosis but also for monitoring of anti-cancer therapy [100]. Detection of ctDNA variants before and after anti-cancer therapy could provide profound information for therapeutic resistance prediction, evaluation of therapy efficacy and tumor dynamics monitor during treatment, thus facilitating individualized treatment decisions $[101,102]$.

\section{Surgery}

The level of ctDNA and mutation frequency commonly changes after successful curative surgery. Before surgery, cancer patients have high level of ctDNA. The level generally decreases upon anti-cancer therapy, such as resection, chemotherapy and radiation therapy. If residual disease exists and clinical recurrence occurs, the level would rapidly increase [19]. In addition, ctDNA could assist both quantitative and qualitative assessments of disease progression as a continuous variable correlated with outcome [19].

In patients with resectable colorectal cancer, higher amount of preoperative [19] circulating tumor DNA has been associated with disease recurrence and poor prognosis. However, more researchers have focused on postsurgical plasma samples. Studies in ovarian cancer [103], pancreatic $[104,105]$ adenocarcinoma, colorectal cancer $[74,106,107]$ have indicated that detection of ctDNA after surgery predicted clinical relapse and poor outcome. Furthermore, the results in locally advanced rectal cancer (larc) [74] demonstrate that the detection of circulating tumor DNA prior to any treatment is not predictive of disease recurrence. Postsurgery ctDNA level analysis could stratify cancer patients into subsets that are at high or low risk of relapse, thus aiding the selection of subsequent adjuvant treatments, such as chemotherapy [74, 107]. ctDNA is considered to be superior for detecting relapse than protein tumor biomarkers [19, $106,108]$ and CT scan $[104,105]$ because it has a higher positive predictive value than protein tumor biomarkers and can detect the condition up to 6.5 months earlier than with CT imaging in pancreatic $[104,105]$ adenocarcinoma.

\section{Drug}

ctDNA has significant advantages in the real-time monitoring of drug efficacy due to its biological properties. ctDNA detection of cancer patients allows the early assessment of the drug response, especially the identification of therapeutic resistance, thus helping physicians improve therapeutic strategies in a timely manner to reduce drug toxicity and achieve better efficacy.[109].

Taking the lung cancer field as an example, by detecting mutations in specific genes in ctDNA, there is a possibility that researchers could predict the following drug response. Patients with detectable EGFR gene mutations in circulating tumor DNA, which is generally concordant with that of tumor tissue [110], may have a higher response rate to epidermal growth factor receptor tyrosine kinase inhibitor (EGFR-TKI) than unmutated patients [111]. Moreover, analysis of circulating tumor DNA can supplement the identification of acquired resistance-associated mutations in patients with advanced cancer.[24] For example, the detection of T790M implies that the patient is likely to develop tolerance to gefitinib, erlotinib, or a combination of erlotinib and pertuzumab. [112] The presence of KRAS mutations in plasma may be a marker of a poor response to chemotherapy. [113] Moreover, monitoring of circulating DNA is informative for earlier evaluation of the treatment response than the radiographic image [114]. If the drug is effective, the drug-sensitive tumor-specific mutations in ctDNA will usually be reduced; otherwise, drug resistance will be manifested in elevated ctDNA levels. Interestingly, after EGFR-TKI therapy, ctDNA with specific mutations also sometimes transiently increases. This phenomenon may be observed in tumors with a few dead cells, for dead tumor cells increase due to drugs and thus release more ctDNA [115].

As occurs in lung cancer, circulating DNA can act as a response, resistance and prognosis biomarker in prostate cancer. BRCA2 reversion mutations are associated with the resistance of inhibitors of the DNA repair protein poly (ADP)-ribose polymerase (PARPi), such as olaparib and talazoparib in prostate cancer patients.[116] Evaluation of the plasma androgen receptor (AR) gene status (including AR amplification, multiple AR mutations, etc.[117]) identifies castration-resistant prostate cancer (CRPC) patients with a worse outcome and resistance to conventional prostate cancer drugs such as enzalutamide and abiraterone $[118,119]$. In addition, the detection of RB1 loss [120] and germline DNA repair defects [117] is also associated with the poor response to therapy targeting AR. A study analyzing targeted and whole-exome sequencing of serial circulating-free DNA (cfDNA) 
samples collected during a Phase II trial (TOPARP-A) of the PARPi olaparib in metastatic prostate cancer demonstrated that cfDNA analyses have the potential to detect all somatic mutations identified in tumor biopsies as well as new mutations emerging only upon disease progression. These new mutations may be caused by therapeutic selective pressures [121].

Also in the breast cancer field, in a phase III clinical trial of breast cancer treatment with CDK4/6 inhibitors, the detection of changes in ctDNA PIK3CA levels after 15 days of treatment predicts progression-free survival (PFS) after treatment [122]. Additionally, analysis of the ESR1 mutation in ctDNA can be used to predict whether patients will be resistant to the next aromatase inhibitor treatment. Although ESR1 mutations are rarely detected in ctDNA in helper aromatase inhibition therapy, they often appear during the treatment of metastatic lesions, suggesting that micrometastases and apparent metastatic cancers have different mechanisms of resistance to targeted therapies [123]. As a whole, early monitoring of ctDNA levels during treatment can predict the efficacy of the therapeutic regimen in patients.

Regarding other types of cancers, research has indicated that multiple recurrent point mutations of ctDNA fibroblast growth factor receptor (FGFR) 2 kinase domain can be detected during the progression of acquired anti-BGJ398 intrahepatic cholangiocarcinoma (ICC). This result indicates that ctDNA FGFR2 mutations could be used to identify resistance of the FGFR inhibitor BGJ398[124]. Studies examining circulating free DNA responses to the drug have also been conducted in ovarian carcinoma [125], colorectal cancer [65, 126, 127] and pancreatic cancer [128]. Moreover, regorafenib seems to be consistently associated with a clinical benefit in patients based on mutational status and protein biomarker concentration, indicating that the detection of circulating DNA could be a viable approach for noninvasive analysis of the tumor genotype in real time [129].

ctDNA can supplement tumor tissue analysis in evaluations of anti-cancer drug responses to help design new strategies for personalized treatment. ctDNA analysis may be more convenient in clinical applications because it can significantly reduce the data turnover time. However, its clinical value still requires support from additional large-scale studies.

\section{Radiotherapy}

Radiotherapy is the mainstay treatment modality for many cancers. However, the increased incidence of recurrence and distant metastasis may lead to the emergence of radioresistance [130]. Detection of circulating DNA may be a criterion for assessing whether postoperative radiotherapy is required. Detection of cfDNA quantification and KRAS and EGFR mutations in the plasma of 168 patients with lung cancer before and after surgery [131] have shown that the analysis of cfDNA could be regarded as a supplement to tissue biopsy. Grading lung cancer patients at cfDNA levels 30 days after surgery may help to select patients who need to undergo chemoradiation after surgery.

\section{ctDNA and metastasis}

The invasion and metastasis of tumor cells are prominent features that are closely related to the prognosis of patients. In clinical practice, the diagnosis of tumors should be performed simultaneously with the diagnosis of primary tumors, lymph node metastasis, and distant metastasis. The tumors are defined as different stages, and the treatment plans are developed according to their stages. At present, the assessment of tumor staging before surgery depends on CT and other imaging methods and biopsy. Recent studies have shown that analyzing the ctDNA of a patient may be helpful in understanding the condition of a patient's metastasis. The level of ctDNA was detected in 640 patients with different types of tumors [100], and the results showed that ctDNA was detected in $>75 \%$ of advanced patients but $<50 \%$ of early patients. The analysis of patients with a single kind of tumors also showed that the level of ctDNA might be associated with tumor metastasis. In stage II-IV NSCLC patients, ctDNA can be detected in 100\% of the blood sample, and only $50 \%$ of patients in stage I can be detected [96]. They also found that the level of ctDNA in newly diagnosed patients with advanced lung cancer is associated with bone metastases and liver metastases [132]. The level of ctDNA in patients with early and late tumors may be related to a variety of factors. In addition to the tumor volume $[125,133,134]$, it is also associated with factors such as necrosis, ki67, pathological type, lymph node metastasis, hematogenous metastasis, allele frequency, EpCAM-positive CTC mutation [135] and others [136]. The condition of ctDNA not only reflects the tumor burden but also relates to tumor metabolism, which indicates the biological behavior of the tumor [21].

Interestingly, different metastatic lesions have their own characteristics, and ctDNA detection can reflect these differences [126]. In therapy-resistant patients with colorectal cancer and liver metastases, MEK1 (K57T) resistance mutations are detected by tissue biopsy and ctDNA detection. The ctDNA analysis can also detect previously undetected KRAS (Q61H) mutations [65]. The mutation level increases after treatment, and the mutation is detected in a separate metastatic biopsy. Increased levels of FGFR3 and PIK3CA mutations in blood and urine ctDNA in bladder cancer patients suggest tumor metastasis [137]. A recent study followed the 
evolutionary perspective of the ctDNA profiles of NSCLC primary tumors and the presence of seven different metastatic lesions. The metastases originated from the same subclone. With the appearance of metastasis at various sites, the ctDNA profile of patients gradually changed. The researchers could observe several mutations in the characteristics of the primary tumor, mutations in the metastatic features, mutations in the primary tumor and metastasis, and mutations in the metastatic characteristics in one site [99]. These results show that the detection of ctDNA may reflect the presence or absence of metastasis in the tumor and offer suggestions about the site of metastasis. It is also worth noting that assessing individual foci in the future may not be sufficient to determine appropriate treatment options.

Monitoring ctDNA during treatment may detect the metastasis as early as possible. A retrospective study comparing current clinical surveillance methods found that in an average of $86 \%$ of patients who had passed ctDNA testing, metastasis could be detected 11 months earlier [138].

Moreover, remarkable concordance of driver DNA alterations in ctDNA and matched metastatic tissue biopsies was discovered in mCRPC. This finding suggests that ctDNA assays can be confidently used to molecularly stratify patients and predict prognosis [139]. However, essential drivers of therapy resistance clearly detected in ctDNA can be missed by a single metastatic tissue biopsy. Therefore, an important advantage of ctDNA is its ability to integrate somatic information from more than one metastatic lesion and thereby survey the intrapatient tumor heterogeneity.

\section{ctDNA and tumor metabolism}

Tumor cells have specific types of metabolism to facilitate tumor growth, which is known as the Warburg effect. The common feature of this phenomenon is increased glucose uptake and fermentation of glucose to lactate.[140] Based on the phenomenon that tumor cells take up more glucose than normal cells, in recent years, 18F-fluoro-D-glucose positron emission tomography/ computed tomography (18F-FDG PET/CT) has been used to detect tumor metabolic activity.[141] Many studies have shown that 18F-FDG PET/CT facilitates tumor diagnosis, prognosis prediction and assessment of the therapeutic response.[141-145] Moreover, studies examining the correlation between cfDNA and metabolic tumor burden (MTB) measured by 18F-FDG PET/CT have also be conducted. Compared with 18F-FDG PET/ $\mathrm{CT}$, the cfDNA level is not a simple measure of tumor burden, but it correlates to a complex tumor metabolism and biology, which makes it a better biomarker to reflect the biological behavior or aggressiveness of the tumor.
[21, 146, 147] In addition to 18F-FDG PET/CT, lactate dehydrogenase (LDH), which catalyzes the final step of glycolysis, has also been described by researchers. Serum $\mathrm{LDH}$ is also a possible marker for metastasis, prediction of therapeutic efficacy and prognosis.[148-151] Studies on melanoma have demonstrated that ctDNA has a higher sensitivity than LDH to detect disease progression and treatment response, making it a more promising blood-based biomarker than LDH.[152, 153]

Mitochondria provide energy for cell functioning and contain their own genetic material, mitochondrial DNA (mtDNA), which encodes 13 proteins of the mitochondrial proteome. Mitochondrial DNA and protein are of great importance for bioenergetics, especially oxidative phosphorylation, in both normal and tumor cells [154]. Alterations of mtDNA have been observed in multiple kinds of cancers [155]. Moreover, mtDNA damage may be involved in tumor progression and metastasis [156]. As a result, mitochondria are considered to be a possible therapeutic target. For example, mitochondrial proteins, such as Lon protease, Mitofusin-2, and TFAM, among others, may be potential therapeutic targets [157] for bladder cancer. Mitochondrially targeted vitamin E succinate (MitoVES) [158] can influence mtDNA transcripts, inhibit mitochondrial respiration, reduce the generation of reactive oxygen species, and thus suppress the proliferation of cancer cells. A photochemotherapy (PCT) [159] strategy targeting mtDNA using near-infrared (NIR)-assisted tumor-specific Fenton reactions has also been proposed. In vitro and in vivo experiments have also confirmed that inhibition of gasotransmitter hydrogen sulfide ( $\mathrm{H} 2 \mathrm{~S})$-producing enzymes increases the sensitivity of lung adenocarcinoma cells to chemotherapeutic agents via induction of mitochondrial dysfunction [160].

Compared with nuclear DNA, mtDNA has a higher copy number per cell and a higher mutation rate, which makes tumor-specific circulating mtDNA a potential biomarker of tumor "liquid biopsy" [161]. Recent studies have shown that the detection of circulating mtDNA content and tumor-specific mtDNA mutations could be a noninvasive tool to predict the risk of developing bladder cancer [157] and hepatocellular carcinoma in HBV patients [7]. mtDNA is also a potential marker in blood for the early detection of bladder cancer [157] and glioblastoma [162]. Elevated mtDNA levels have been observed in the plasma of prostate cancer patients with poor 2-year survival, which indicates that circulating mtDNA could be used to predict prognosis [163].

Although exome sequencing can accurately detect mitochondrial single nucleotide polymorphisms, (SNPs) [164], whether it is feasible to trace mtDNA in blood with current methods remains uncertain. A recent study showed only $17 \%$ tumor-specific mtDNA variants were 
detected in cfDNA with much lower allele frequencies and extensive heterogeneity [161]. Therefore, detecting approach should be improved before further study of circulating mtDNA.

\section{ctDNA, tumor heterogeneity, and therapeutic resistance}

Many studies have confirmed that ctDNA test results are related to drug resistance in cancer patients. Moreover, clinical practice and basic research have validated that the existence of tumor heterogeneity fuels resistance, thus leading to the failure of anticancer therapy. Analysis of ctDNA chromatin modifications can display the heterogeneity of tumors and has great potential for predicting tumor drug resistance.

Tumor heterogeneity refers to the presence of differences in tumor tissue, which mainly contains the following aspects: 1. Individual differences: Patients with the same type of tumor have differences in pathology, tumor biobehavior, responsiveness to treatment, and prognosis. 2. Intratumoral heterogeneity (spatial heterogeneity): In a single patient, there are many differences ranging from genotypes to phenotypes among each tumor cell located in the same tumor tissue block. 3. Temporal heterogeneity: Alterations in the features as well as the genetic makeup of tumors at different stages of development (e.g., primary tumors and metastases) [165].

The presence of tumor heterogeneity, especially intratumoral heterogeneity, leads to the inefficacy of single anti-cancer therapy (targeted drug therapy, in particular) since it is mostly only effective for a portion of the tumor cells. Taking melanoma as an example [166], some patients with melanoma have been clinically found to have poor outcomes when given BRAF/MEF inhibitors, and further studies have found that the tyrosine kinase receptor AXL is highly expressed on the surface of tumor cells that react poorly to BRAF/MEF inhibitors. The sensitivity of tumor cells to AXL-107-MMAE treatment depends on the expression level of AXL receptor on the tumor cell surface, which inspired the synthesis of AXL-107-MMAE, a drug that can effectively kill tumor cells with a high level of AXL via combining AXL antibody with the microtubule-damaging drug monomethyl auristatin E (MMAE). Similar cases have also been reported in myeloma [167, 168], NSCLC [169], breast cancer [170], and colon cancer, among others. Tumor heterogeneity also plays a significant role in acquired drug resistance, the mechanisms of which remain equivocal [171]. To tackle the therapeutic difficulties introduced by tumor heterogeneity, tumor subpopulations should be divided according to the specific characteristics of each subpopulation. For instance, topographic single cell sequencing (TSCS) was utilized to analyze genomic copy number profiles in a tumor subpopulation, and a multiclonal invasion model between ductal carcinoma in situ (DCIS) and invasive ductal carcinoma (IDC) was established [172], which provided insight for tagging tumor subpopulations and their evolution. Accordingly, new drugs targeting those specific markers should be developed for multidrug combination therapy. In contrast, simple and accurate detection methods should be designed to locate and analyze tumor heterogeneity, shedding light on optimized treatment decisions.

The analysis of ctDNA can reflect tumor heterogeneity, hence improving drug resistance prediction and therapeutic decisions. In the study of tumor tissue DNA and paired ctDNA, researchers found that some patients' partial mutation sites could be detected in ctDNA but not in tumor tissues. This phenomenon can be observed in colorectal cancer, myeloma, metastatic castration-resistant prostate cancer and lung cancer [39, $110,139,173]$. In addition, considering that ctDNA is derived from the passive release of systemic dead tumor cells and the active release of tumor cells, ctDNA is able to paint a better picture of the genomic alterations of tumor patients and eradicate misleading tumor heterogeneity in both tumor diagnosis and drug resistance analyses. However, the source of circulating DNA remains diverse. In addition to tumor cells, circulating DNA can be derived from leukocytes [97] and epithelial cells, among others. Solutions include the establishment of rigorous calling parameters to maintain the platform specificity, potentially at the expense of analytical sensitivity in terms of the detection of low-frequency mutations [19]. As a result, the further application of ctDNA detection in clinical practice requires advanced techniques to reduce the effects of background DNA without compromising its sensitivity.

Compared with tissue biopsies, ctDNA presents a more comprehensive picture of the existence of various subpopulation cells in a tumor, given that plasma samples theoretically contain ctDNA from multiple metastatic examples (Fig. 3). In some scenarios, ctDNA might enable the identification of alterations that were not detected by tissue genotyping, some of which have therapeutic implications. For instance, a clinical study [174] has shown that patients with MET-amplified esophagogastric cancer (EGC) develop resistance after about two months of MET inhibitor therapy, mainly due to the rapid growth of non-MET (EGFR or HER-2) amplified tumor cell subpopulations. Test results of those patients revealed that before and during the use of MET inhibitors, an increase in copy number of EGFR can be observed in ctDNA. Additionally, the increase in ctDNA EGFR copy number is consistent with the growth of MET inhibitor resistant tumor cells. However, the sensitivity of ctDNA platforms had previously limited the 


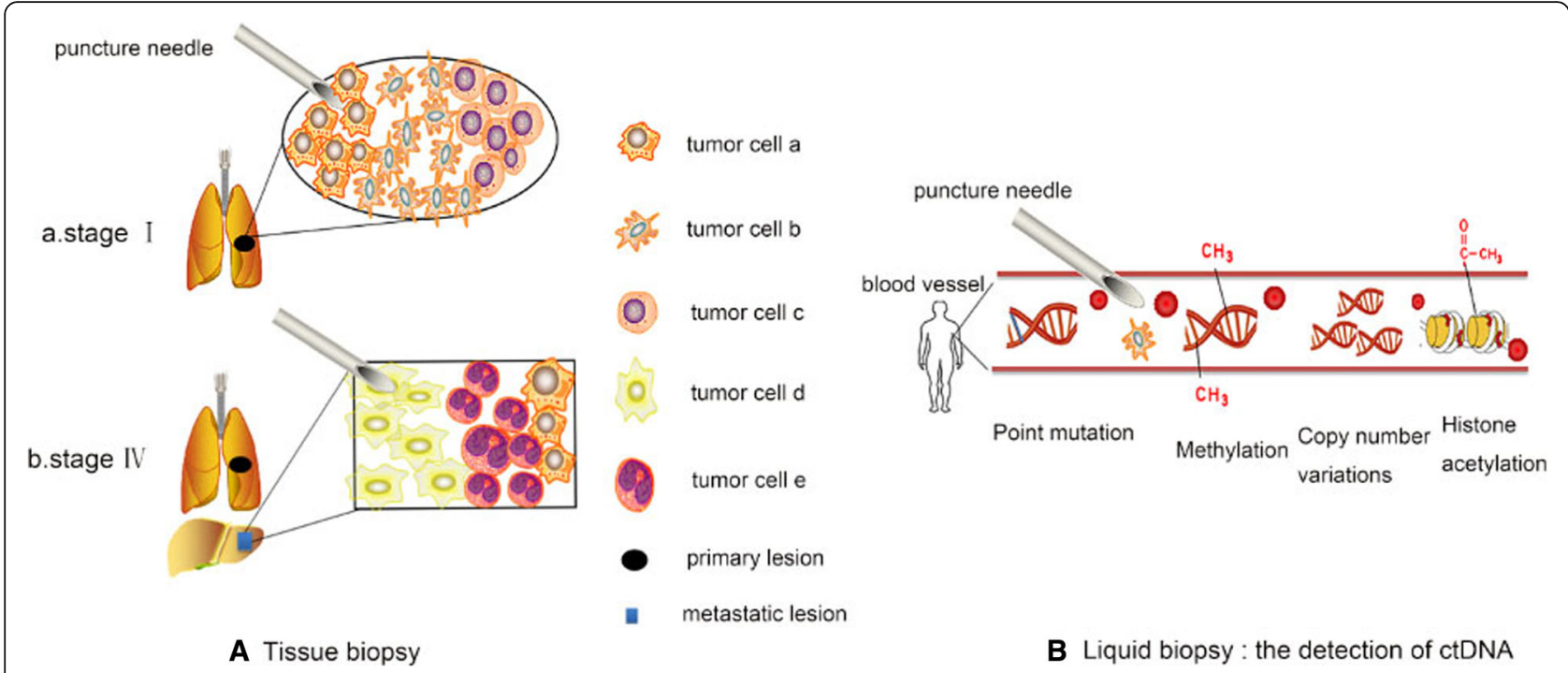

Fig. 3 Comparison of traditional tissue biopsy and "liquid biopsy". a: Diagnosis and anti-tumor therapeutic decisions are limited by temporal and intratumoral heterogeneity using traditional tissue biopsies. A mass of tumor tissue consists of several blocks of tumor cell subtypes, while tumors simultaneously at different stages of development (e.g., primary tumors and metastases) can also carry different features. Therefore, samples obtained from tissue biopsy may not provide comprehensive information for diagnosis and therapeutic decisions. b: Analysis of ctDNA can present profiles of point mutations, methylation, copy number variations, and histone acetylation, among others, thus providing relatively comprehensive information about the tumor of interest

application of ctDNA-based analyses in patients with localized and invasive cancers, although developments in the past year have improved the outcome in patients. As a result, researchers have exerted numerous efforts to optimize method selection and invent novel technologies. Taking NSCLC as an example, multiple cross-platform comparisons of technologies encompassing digital and nondigital platforms have been conducted to detect EGFR mutations. Most of the results have demonstrated that both platforms are capable of sensitive and specific detection of EGFR-TKI-sensitizing mutations using patients' plasma samples $[175,176]$.

In contrast to current ctDNA detection approaches that typically interrogate a single locus and have low multiplexing capabilities, such as digital droplet PCR60, next-generation sequencing (NGS) methodologies can be used to interrogate larger portions of the tumor genome and track multiple tumor-associated mutations. For instance, some researchers utilized a ctDNA-based NGS analysis of blood samples in 179 patients and identified three subgroups according to their genetic mutations, which favored predictions of drug resistance [177]. Similar practices have also been adopted in prostate carcinoma [178], colorectal cancer [86], and hepatocellular carcinoma [179] among others. Of note, ct-DNA-based NGS analyses have also been conducted in a much larger cohort of 670 patients with more diverse tumors, with encouraging results [180]. In addition, an ultradeep ctDNA-based NGS assay was developed, which underlined the feasibility of performing mutational analysis for
61 cancer-related genes with a simplified workflow, as well as linking cfDNA with systemic treatment success [181]. In summary, the aforementioned advancements will greatly encourage broader investigations of the application of this technology for precision medicine in cancer management.

\section{Clinical trails}

A growing interest in precision medicine and the availability of targeted agents has heightened interest in genomic biomarker-based clinical trials. Trials of targeted therapies intended to show enhanced efficacy in patient subpopulations are increasingly common, such as those with a known biomarker value or genetic tumor mutation. By enabling smaller trials, prognostic enrichment can produce greater efficiency in evaluating new interventions, with potential benefits for patients, sponsors, and public health. With the assumption that preliminary results show evidence that a biomarker such as ctDNA has predictive value, there has been a surge of interest in biomarkers for multiple purposes [182], including the early detection of disease, improved diagnosis and treatment optimization.

There have been 141 clinical trials of ctDNA worldwide, and a total of 17 projects have been completed to date. From the perspective of regional distribution, Europe and East Asia are the main concentrated areas. Among experimental studies of tumors, non-small cell lung cancer has accounted for a total of 42 items, gynecological tumors including breast cancer, ovarian 
cancer and cervical cancer a total of 20, colorectal cancer 17 items, and prostate cancer and pancreatic tumors 5 items each. There are also a number of clinical studies on tumors such as lymphoma, liver cancer, and head and neck cancer. Based on the type of experimental research, the vast majority of studies are open-label as well as observational studies, and approximately forty percent are parallel assignment. The primary purpose of these experiments is to explore the clinical role of ctDNA as a biomarker for liquid biopsy and patient recruiting. They also focus on the changes in the efficacy of the related chemotherapy and dynamically monitor the efficacy of radiotherapy in combination with imaging. Additionally, one popular use of biomarkers is for the "prognostic enrichment" of clinical trials. There are also institutions that have conducted clinical trials on immunotherapy for current research hotspots. For instance, IMPACT designed by the Shen Lin team at Peking University, is ongoing, the subject of which is identifying MSI status from ctDNA in Chinese patients with refractory advanced solid tumors. The primary outcome measure of the trial is the incidence of MSI-H across different cancer types in Chinese patients at 2 years diagnosed by SPANOM. The estimated enrollment will be 8000 participants, which means the outcome may improve immunotherapy treatment of Chinese patients.

Therefore, we highlight some practical considerations and challenges faced within selected recently completed or ongoing biomarker-based clinical trials investigating ctDNA.

There are few trails with available study results, one of which is NCT02418234. The final results of the NCT02418234 trial and its inherent challenges are as follows: a) the enrollment comprises 314 patients, $56.4 \%$ female and $43.6 \%$ male, and nearly $80 \%$ were stage IV; and b) 97 of the 314 patients with NSCLC resistance to tyrosine kinase inhibitors (TKIs) carried the T790M mutation in ctDNA, as detected by ARMS assay.

An ongoing c-TRAK-TN prospective, multicenter study aims to assess whether ctDNA screening can be used to detect residual disease following standard primary treatment for triple-negative breast cancer, and it will also assess the safety and activity of the investigational medicinal product pembrolizumab. Between 2017 and 2022, over 200 patients aged 16 years or older were recruited in the UK. Blinded serial ctDNA screening every 3 months from the point of registration and completion of primary treatment for triple-negative breast cancer will be performed in the same sample. If a ctDNA positive result occurs on or before the 12-month ctDNA screening assessment, the patient will be randomized by the ICR-CTSU at a 2:1 ratio to the pembrolizumab treatment arm or observation arm. LIBERTI, a prospective, multicenter clinical study in the US aimed to learn more about changes in cell-free tumor DNA in liquid biopsy as they relate to treatment and response to treatment. Another goal of the study was to correlate the presence of ctDNA following complete surgical resection with disease-free survival in more than 500 patients with early-stage NSCLC by evaluating the clinical performance of ctDNA as a signal indicative of the relationship between changes in ctDNA during surveillance and tumor relapse.

Another newly open marker-targeted master protocol is SPECIAL, which uses next-generation sequencing (NGS) and whole-exome sequencing (WES) to assign patients with metastatic solid tumors to individual single-arm targeted studies, in which it is hypothesized that an enhanced tumor response will be achieved with targeted therapy. Additionally, patients will undergo tumor and blood sample collections at serial time points (maximum of 3 ) to investigate the clonal evolution of tumors under the selective pressure of ICIs. Because a single SPECIAL subprotocol will enroll 14 patients from a number of different tumor types (e.g., breast and colon) that likely have different prognostic or treatment response profiles, it is possible that the primary endpoint (tumor response rate) of the subtrial will vary across organ classes regardless of the marker status and challenge interpretation of the results. The SPECIAL trial was initiated in April 2015 in Canada.

\section{The drawbacks of ctDNA in clinical applications}

Despite the skyrocketing development of ctDNA analysis mentioned above, it is important to accentuate that the efficacy of this model under clinical settings is yet to be determined. To be more specific, current drawbacks hindering its wide-scale clinical applications can be elaborated as the following.

The preanalytical phase mainly contains the identification and selection of an appropriate test, specimen collection and transport. However, several obstacles hinder the proper implementation of the preparation. First, there is a dearth of consistent, reproducible and trustworthy protocols encompassing the blood sample collection, isolation and purification of ctDNA from blood and transport. Without uniform and optimized guidelines for the procedures, poor preanalytical sample handling techniques could weaken the test results, introduce additional costs, or even lead to adverse events in some patients [183]. For instance, there is great discordance between the use of ctDNA collecting tubes, which mainly include ethylenediaminetetraacetic acid (EDTA), CellSave, cell-Free DNA blood collection tubes (BCTs) and Streck. They each cast different effects on cfDNA levels, making them suitable for their respective research purposes $[184,185]$. The low isolation efficiency and incompatibility with analytic techniques of ctDNA 
isolation kits must also be addressed in future studies [186]. In addition, there is an urgent necessity to further explore the effects of the storage temperature as well as the preservation time, as unfavorable conditions may increase cell lysis and interfere with the test results [187, 188]. To effectively circumvent factors that may degrade or contaminate the ctDNA specimen, exhaustive studies are needed to evaluate the influence of the repertoire of variables concerning specimen processing, which contributes to the establishment of an enhanced ctDNA analysis pipeline. Moreover, ctDNA analysis should be a purpose-driven test, with sufficient a priori knowledge of mutations of interest (e.g., KRAS, BRAF mutations in colon cancer) under most circumstances. However, the limited scope of test variants may hamper the detection of broader tumor types or novel mutations.

The analytical phase, however, mainly includes the laboratory assay itself. The number of variants identified by genotyping has increased dramatically, creating challenges for the interpretation of the clinically actionable variants and for delivering meaningful data in a timely fashion to guide patient care [58]. The current situation calls for tests such as next-generation sequencing (NGS)-based methods. Nevertheless, each NGS-based method has its own characteristics, which must be weighed by clinicians when carrying out the assay. The common challenges for these approaches, as a result, mainly lie in the discordance of the sequencing data in different assays, with different established parameters. The equivocal range of variant calls can be variable, and therefore rigorous repeats of independent NGS assays or validation of suspected mutation sites are needed [189].

The postanalytical phase mainly consists of data analysis, interpretation of the results and reporting. In this phase, clear outcome interpretations should be expected before the analysis is implemented [58]. However, the major hurdles that hinder cross-assay interpretations comprise the exact origin of the ctDNA, the shedding behavior of the ctDNA, and the concentration of ctDNA. According to previous knowledge, the origin of ctDNA can vary. Apart from malignant tumor cells, it has been reported that benign tumors (e.g., adenomas) harboring overlapping malignant mutations can also release ctDNA in the early stage [190, 191], which may lead to false-positive test results. Nevertheless, it has also been illustrated that benign lesions are unlikely to release significant quantities of ctDNA, making them less amenable for liquid biopsies [100, 192]. Clonal hematopoiesis with somatic mutations, which is often related to aging and confers high relative risks to hematopoietic cancer in the elderly, does not actually translate into many hematopoietic cancers [193, 194]. Therefore, the low absolute risks of clonal hematopoiesis towards cancer can introduce inaccuracies in the test results and unnecessary patient anxiety. In addition, false-negative results can also derive from the following factors. First, little is known about the shedding behavior of different types of cancer cells, as well as patient-specific factors that may influence cfDNA release. These factors include pregnancy, smoking and autoimmune diseases, among others [195]. As a result, the elusive pattern of ctDNA release might lead to the highly variable fraction of ctDNA originating from the tumor cells, ranging from $<0.1 \%$ to $>50 \%$ of the total cfDNA [15]. The anatomical barrier of the human body, mainly the blood-brain barrier, can also cause false-negative results. The ctDNA released from tumor cells into the central nervous systems can be impeded by the blood-brain barrier from entering the circulation [100]. Even for the ctDNA successfully released into the circulation, however, there is a great chance that they might be masked by germline DNA resulting from nontumor cells (such as leukocytes). Moreover, it is noteworthy that since ctDNA is usually conceived as the release products when tumor cells undergo apoptosis or necrotic cell death [196], high numbers of resistant tumor cells can escape the detection of ctDNA analysis. Overall, these underlying problems will perplex researchers in analyzing, interpreting and reporting test results.

Despite the vital significance of ensuring the high analytical validity of ctDNA analysis by improving the peri-phases of ctDNA analysis, the clinical utility and validity of ctDNA should be given even greater importance. In clinical scenarios, clinical validity means that the ctDNA test result is associated with whether the patient truly has cancer, while clinical utility refers to the ability of ctDNA to ameliorate the patient outcome as a biomarker [197]. We have presented the studies that support the clinical validity of ctDNA in the above sections, but it remains uncertain whether ctDNA analysis has clinical utility. There is a lack of appropriately designed clinical trials for the validation of ctDNA analysis, whether they be ctDNA stand-alone diagnostic tests or tests that compare information provided by ctDNA with tissue genotyping [195]. Despite some progress [196, 198], further studies are needed to validate the clinical utility of ctDNA.

To conclude, the detection of ctDNA before treatment facilitates the early detection of differential tumor cell subpopulations, thus aiding appropriate treatment decisions. It may also help with the prevention of tumor recurrence by monitoring postsurgical minimal (or molecular) residual disease (MRD) [199]. After the start of treatment, regular monitoring of ctDNA facilitates the early detection of drug resistance due to different mechanisms (acquired genetic alterations or genetic changes that are always present but not detected). 


\section{Perspectives}

According to recent advanced studies, ctDNA analysis could be a promising approach to evaluate the treatment response and tumor metastasis condition, thus contributing to the development of the individualized treatment design. More importantly, the analysis of ctDNA is the only method for evaluating liquid biopsies that are recommended by the FDA and the EMA for cancer diagnosis and treatment monitoring. Therefore, ctDNA is a promising biomarker that supplements traditional biomarkers and current screening approaches. However, challenges persist before this technique can be implemented in wide clinical practice in the future. First, further refinement of sequencing is crucial to detect ctDNA specifically with higher sensitivity. Interestingly, recent research has demonstrated improved sensitivity primarily by coisolating the RNA carried in exosomes and ctDNA rather than ctDNA alone, providing an alternative method to maximize the clinical sensitivity of the liquid biopsy assay [200]. Second, research on a larger scale should be conducted using ctDNA sequencing to explore more alterations associated with anti-tumor therapeutic resistance carried by ctDNA. In this case, a better understanding of the ctDNA profile could assist physicians in the treatment design. Finally, more attention could be focused on the exploration of the difference between the primary tumor ctDNA profile and those of metastases to realize the remarkable potential of ctDNA in supervising anti-tumor therapy and evaluating prognosis.

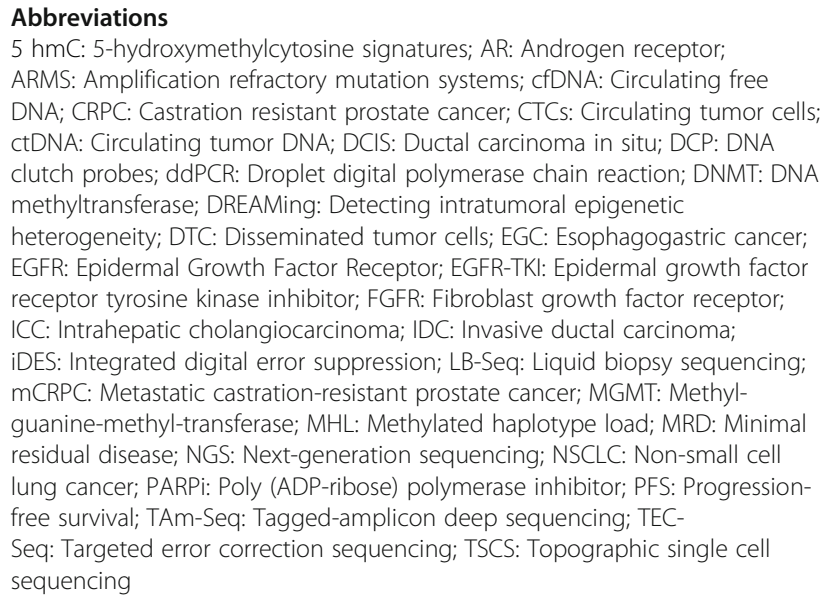

\section{Acknowledgments}

This manuscript has been read and approved by all the authors for publication and has not been submitted or under consideration for publication elsewhere

\section{Funding}

This work was supported by the National Natural Science Foundation of China [81672787 (Y. Tao), 81672991 and 81874139 (S. Liu)]; the Fundamental Research Funds for the Central South Universities [zy20180925 (L. Zhang)]; and the National Basic Research Program of China [2015CB553903 (Y. Tao)].

\section{Authors' contributions}

Conception and design: FY, YT Development of methodology: LZ, YL, SL, FZ, YM, FY, ZC, YT Acquisition of data: LZ, YL, SL, FZ, YM, FY, ZC, YT. Analysis and interpretation of data (e.g., statistical analysis, biostatistics, computational analysis): LZ, YL, SL, FZ, YM, FY, ZC, SL, YT. Writing, review, and/or revision of the manuscript: $L Z, Y L, S L, F Z, Y M, F Y, Z C, S L, Y T$. Study supervision: FY, YT. All authors read and approved the final manuscript.

\section{Competing interests}

The authors declare that they have no competing interests.

\section{Publisher's Note}

Springer Nature remains neutral with regard to jurisdictional claims in published maps and institutional affiliations.

\section{Author details}

${ }^{1}$ Key Laboratory of Carcinogenesis and Cancer Invasion, Ministry of Education, Department of Pathology, Xiangya Hospital, Central South University, 87 Xiangya Road, Changsha 410008, Hunan, China. ${ }^{2} \mathrm{NHC}$ Key Laboratory of Carcinogenesis (Central South University), Cancer Research Institute and School of Basic Medicine, Central South University, 110 Xiangya Road, Changsha 410078, Hunan, China. ${ }^{3}$ Department of Oncology, Institute of Medical Sciences, Xiangya Hospital, Central South University, 87 Xiangya Road, Changsha 410008, Hunan, China. ${ }^{4}$ Department of Thoracic Surgery,

Second Xiangya Hospital, Central South University, Changsha 410011, China.

Received: 5 November 2018 Accepted: 26 February 2019

Published online: 09 March 2019

\section{References}

1. Heist RS, Engelman JA. SnapShot: non-small cell lung cancer. Cancer Cell. 2012;21:448.e442.

2. Lo YM, Chan KC, Sun H, Chen EZ, Jiang P, Lun FM, Zheng YW, Leung TY, Lau TK, Cantor CR, Chiu RW. Maternal plasma DNA sequencing reveals the genome-wide genetic and mutational profile of the fetus. Sci Transl Med. 2010;2:61ra91.

3. Sacher AG, Paweletz C, Dahlberg SE, Alden RS, O'Connell A, Feeney N, Mach SL, Janne PA, Oxnard GR. Prospective Validation of Rapid Plasma Genotyping for the Detection of EGFR and KRAS Mutations in Advanced Lung Cancer. JAMA Oncol. 2016;2:1014-22.

4. Umetani N, Giuliano AE, Hiramatsu SH, Amersi F, Nakagawa T, Martino S, Hoon DS. Prediction of breast tumor progression by integrity of free circulating DNA in serum. J Clin Oncol. 2006;24:4270-6.

5. Ludovini V, Pistola L, Gregorc V, Floriani I, Rulli E, Piattoni S, Di Carlo L, Semeraro A, Darwish S, Tofanetti FR, et al. Plasma DNA, microsatellite alterations, and p53 tumor mutations are associated with disease-free survival in radically resected non-small cell lung cancer patients: a study of the perugia multidisciplinary team for thoracic oncology. J Thorac Oncol. 2008;3:365-73.

6. Nawroz H, Koch W, Anker P, Stroun M, Sidransky D. Microsatellite alterations in serum DNA of head and neck cancer patients. Nat Med. 1996;2:1035-7.

7. Li L, Hann HW, Wan S, Hann RS, Wang C, Lai Y, Ye X, Evans A, Myers RE, Ye $Z$, et al. Cell-free circulating mitochondrial DNA content and risk of hepatocellular carcinoma in patients with chronic HBV infection. Sci Rep. 2016;6:23992.

8. Yong E. Cancer biomarkers: Written in blood. Nature. 2014;511:524-6.

9. Thierry AR, Mouliere F, Gongora C, Ollier J, Robert B, Ychou M, Del Rio M, Molina F. Origin and quantification of circulating DNA in mice with human colorectal cancer xenografts. Nucleic Acids Res. 2010;38:6159-75.

10. Jahr S, Hentze H, Englisch S, Hardt D, Fackelmayer FO, Hesch RD, Knippers R. DNA fragments in the blood plasma of cancer patients: quantitations and evidence for their origin from apoptotic and necrotic cells. Cancer Res. 2001;61:1659-65.

11. Kahlert C, Melo SA, Protopopov A, Tang J, Seth S, Koch M, Zhang J, Weitz J, Chin L, Futreal A, Kalluri R. Identification of double-stranded genomic DNA spanning all chromosomes with mutated KRAS and p53 DNA in the serum exosomes of patients with pancreatic cancer. J Biol Chem. 2014;289:3869-75.

12. Thakur BK, Zhang H, Becker A, Matei I, Huang Y, Costa-Silva B, Zheng Y, Hoshino A, Brazier H, Xiang J, et al. Double-stranded DNA in exosomes: a novel biomarker in cancer detection. Cell Res. 2014;24:766-9. 
13. Demeulemeester J, Kumar P, Moller EK, Nord S, Wedge DC, Peterson A, Mathiesen RR, Fjelldal R, Zamani Esteki M, Theunis K, et al. Tracing the origin of disseminated tumor cells in breast cancer using single-cell sequencing. Genome Biol. 2016;17:250.

14. Chimonidou M, Strati A, Malamos N, Georgoulias V, Lianidou ES. SOX17 promoter methylation in circulating tumor cells and matched cell-free DNA isolated from plasma of patients with breast cancer. Clin Chem. 2013;59: 270-9.

15. Crowley E, Di Nicolantonio F, Loupakis F, Bardelli A. Liquid biopsy: monitoring cancer-genetics in the blood. Nat Rev Clin Oncol. 2013;10:472-84.

16. Koyanagi K, Mori T, O'Day SJ, Martinez SR, Wang HJ, Hoon DS. Association of circulating tumor cells with serum tumor-related methylated DNA in peripheral blood of melanoma patients. Cancer Res. 2006;66:6111-7.

17. Mastoraki S, Strati A, Tzanikou E, Chimonidou M, Politaki E, Voutsina A, Psyrri A, Georgoulias V, Lianidou E. ESR1 Methylation: A Liquid Biopsy-Based Epigenetic Assay for the Follow-up of Patients with Metastatic Breast Cancer Receiving Endocrine Treatment. Clin Cancer Res. 2018;24:1500-10.

18. Diehl F, Li M, Dressman D, He Y, Shen D, Szabo S, Diaz LA Jr, Goodman SN, David KA, Juhl H, et al. Detection and quantification of mutations in the plasma of patients with colorectal tumors. Proc Natl Acad Sci U S A. 2005; 102:16368-73.

19. Phallen J, Sausen M, Adleff V, Leal A, Hruban C, White J, Anagnostou V, Fiksel J, Cristiano S, Papp E, et al: Direct detection of early-stage cancers using circulating tumor DNA. Science Translational Medicine. 2017;9:eaan2415

20. Mao X, Zhang Z, Zheng X, Xie F, Duan F, Jiang L, Chuai S, Han-Zhang H, Han B, Sun J. Capture-Based Targeted Ultradeep Sequencing in Paired Tissue and Plasma Samples Demonstrates Differential Subclonal ctDNAReleasing Capability in Advanced Lung Cancer. J Thorac Oncol. 2017;12: $663-72$.

21. Morbelli S, Alama A, Ferrarazzo G, Coco S, Genova C, Rijavec E, Bongioanni F, Biello F, Dal Bello MG, Barletta G, et al. Circulating Tumor DNA Reflects Tumor Metabolism Rather Than Tumor Burden in Chemotherapy-Naive Patients with Advanced Non-Small Cell Lung Cancer: (18) F-FDG PET/CT Study. J Nucl Med. 2017:58:1764-9.

22. Garcia-Olmo DC, Samos J, Picazo MG, Asensio Al, Toboso I, Garcia-Olmo D. Release of cell-free DNA into the bloodstream leads to high levels of nontumor plasma DNA during tumor progression in rats. Cancer Lett. 2008;272: 133-40.

23. Mandel P. Metais P: [Not Available]. C R Seances Soc Biol Fil. 1948;142:241-3.

24. Leon SA, Shapiro B, Sklaroff DM, Yaros MJ. Free DNA in the serum of cancer patients and the effect of therapy. Cancer Res. 1977;37:646-50.

25. Stroun M, Anker P, Maurice P, Lyautey J, Lederrey C, Beljanski M. Neoplastic characteristics of the DNA found in the plasma of cancer patients. Oncology. 1989;46:318-22.

26. Sorenson GD, Pribish DM, Valone FH, Memoli VA, Bzik DJ, Yao SL. Soluble normal and mutated DNA sequences from single-copy genes in human blood. Cancer Epidemiol Biomarkers Prev. 1994:3:67-71.

27. Vasioukhin V, Anker P, Maurice P, Lyautey J, Lederrey C, Stroun M. Point mutations of the $\mathrm{N}$-ras gene in the blood plasma DNA of patients with myelodysplastic syndrome or acute myelogenous leukaemia. $\mathrm{Br} J$ Haematol. 1994;86:774-9.

28. Chen $X Q$, et al. Microsatellite alterations in plasma DNA of small cell lung cancer patients. Nat Med. 1996:2:1033-5.

29. Esteller M, Sanchez-Cespedes M, Rosell R, Sidransky D, Baylin SB, Herman JG. Detection of aberrant promoter hypermethylation of tumor suppressor genes in serum DNA from non-small cell lung cancer patients. Cancer Res. 1999:59:67-70.

30. Diehl F, Schmidt K, Choti MA, Romans K, Goodman S, Li M, Thornton K, Agrawal N, Sokoll L, Szabo SA, et al. Circulating mutant DNA to assess tumor dynamics. Nat Med. 2008;14:985-90.

31. Diaz LA Jr, Williams RT, Wu J, Kinde I, Hecht JR, Berlin J, Allen B, Bozic I, Reiter JG, Nowak MA, et al. The molecular evolution of acquired resistance to targeted EGFR blockade in colorectal cancers. Nature. 2012;486:537-40.

32. Misale $S$, Yaeger $R$, Hobor S, Scala E, Janakiraman M, Liska D, Valtorta E, Schiavo R, Buscarino M, Siravegna $G$, et al. Emergence of KRAS mutations and acquired resistance to anti-EGFR therapy in colorectal cancer. Nature. 2012;486:532-6.

33. Thierry AR, Mouliere F, El Messaoudi S, Mollevi C, Lopez-Crapez E, Rolet F, Gillet B, Gongora C, Dechelotte P, Robert B, et al. Clinical validation of the detection of KRAS and BRAF mutations from circulating tumor DNA. Nat Med. 2014;20:430-5.
34. Lo YM, Corbetta N, Chamberlain PF, Rai V, Sargent IL, Redman CW, Wainscoat JS. Presence of fetal DNA in maternal plasma and serum. Lancet. 1997;350:485-7.

35. Xu T, Kang X, You X, Dai L, Tian D, Yan W, Yang Y, Xiong H, Liang Z, Zhao GQ, et al. Cross-Platform Comparison of Four Leading Technologies for Detecting EGFR Mutations in Circulating Tumor DNA from Non-Small Cell Lung Carcinoma Patient Plasma. Theranostics. 2017;7:1437-46.

36. Beije N, Helmijr JC, Weerts MJA, Beaufort CM, Wiggin M, Marziali A, Verhoef C, Sleijfer S, Jansen M, Martens JWM. Somatic mutation detection using various targeted detection assays in paired samples of circulating tumor DNA, primary tumor and metastases from patients undergoing resection of colorectal liver metastases. Mol Oncol. 2016;10:1575-84.

37. Jiang P, Chan CW, Chan KC, Cheng SH, Wong J, Wong WW, Wong GL, Chan SL, Mok TS, Chan HL, et al. Lengthening and shortening of plasma DNA in hepatocellular carcinoma patients. Proc Natl Acad Sci U S A. 2015:112:E1317-25.

38. Underhill HR, Kitzman JO, Hellwig S, Welker NC, Daza R, Baker DN, Gligorich KM, Rostomily RC, Bronner MP, Shendure J. Fragment Length of Circulating Tumor DNA. PLoS Genet. 2016;12:e1006162.

39. Kis O, Kaedbey R, Chow S, Danesh A, Dowar M, Li T, Li Z, Liu J, Mansour M, Masih-Khan E, et al: Circulating tumour DNA sequence analysis as an alternative to multiple myeloma bone marrow aspirates. Nature Communications 2017, 8:15086-15086.

40. Das J, Ivanov I, Sargent EH, Kelley SO. DNA Clutch Probes for Circulating Tumor DNA Analysis. J Am Chem Soc. 2016;138:11009-16.

41. Newman AM, Lovejoy AF, Klass DM, Kurtz DM, Chabon JJ, Scherer F, Stehr H, Liu CL, Bratman SV, Say C, et al. Integrated digital error suppression for improved detection of circulating tumor DNA. Nat Biotechnol. 2016;34:547-55.

42. Nguyen AH, Sim SJ. Nanoplasmonic biosensor: detection and amplification of dual bio-signatures of circulating tumor DNA. Biosens Bioelectron. 2015; 67:443-9.

43. Stahlberg A, Krzyzanowski PM, Egyud M, Filges S, Stein L, Godfrey TE. Simple multiplexed PCR-based barcoding of DNA for ultrasensitive mutation detection by next-generation sequencing. Nat Protoc. 2017;12:664-82.

44. Li M, Chen WD, Papadopoulos N, Goodman SN, Bjerregaard NC, Laurberg S, Levin $B$, Juhl $H$, Arber N, Moinova $H$, et al. Sensitive digital quantification of DNA methylation in clinical samples. Nat Biotechnol. 2009:27:858-63.

45. Jeon S, Lee H, Bae K, Yoon KA, Lee ES, Cho Y. Efficient Capture and Isolation of Tumor-Related Circulating Cell-Free DNA from Cancer Patients Using Electroactive Conducting Polymer Nanowire Platforms. Theranostics. 2016;6: 828-36.

46. Forshew T, Murtaza M, Parkinson C, Gale D, Tsui DW, Kaper F, Dawson SJ, Piskorz AM, Jimenez-Linan M, Bentley D, et al. Noninvasive identification and monitoring of cancer mutations by targeted deep sequencing of plasma DNA. Sci Transl Med. 2012;4:136ra168.

47. Fackler MJ, Lopez Bujanda Z, Umbricht C, Teo WW, Cho S, Zhang Z Visvanathan K, Jeter S, Argani P, Wang C, et al. Novel methylated biomarkers and a robust assay to detect circulating tumor DNA in metastatic breast cancer. Cancer Res. 2014;74:2160-70.

48. Wang $X$, Chen F, Zhang D, Zhao Y, Wei J, Wang L, Song S, Fan C, Zhao Y. Single copy-sensitive electrochemical assay for circulating methylated DNA in clinical samples with ultrahigh specificity based on a sequential discrimination-amplification strategy. Chem Sci. 2017;8:4764-70.

49. Song CX, Szulwach KE, Fu Y, Dai Q, Yi C, Li X, Li Y, Chen CH, Zhang W, Jian $X$, et al. Selective chemical labeling reveals the genome-wide distribution of 5-hydroxymethylcytosine. Nat Biotechnol. 2011;29:68-72.

50. Song CX, Yin S, Ma L, Wheeler A, Chen Y, Zhang Y, Liu B, Xiong J, Zhang W, $\mathrm{Hu}$ J, et al. 5-Hydroxymethylcytosine signatures in cell-free DNA provide information about tumor types and stages. Cell Res. 2017;27:1231-42.

51. Pisanic TR 2nd, Athamanolap P, Poh W, Chen C, Hulbert A, Brock MV, Herman JG, Wang TH. DREAMing: a simple and ultrasensitive method for assessing intratumor epigenetic heterogeneity directly from liquid biopsies. Nucleic Acids Res. 2015;43:e154.

52. Adalsteinsson VA, Ha G, Freeman SS, Choudhury AD, Stover DG, Parsons HA Gydush G, Reed SC, Rotem D, Rhoades J, et al. Scalable whole-exome sequencing of cell-free DNA reveals high concordance with metastatic tumors. Nat Commun. 2017:8:1324.

53. Corcoran RB, Chabner BA. Application of Cell-free DNA Analysis to Cancer Treatment. N Engl J Med. 2018;379:1754-65.

54. Cohen JD, Li L, Wang Y, Thoburn C, Afsari B, Danilova L, Douville C, Javed AA, Wong F, Mattox A, et al. Detection and localization of surgically resectable cancers with a multi-analyte blood test. Science. 2018;359:926-30. 
55. Krebs MG, Metcalf RL, Carter L, Brady G, Blackhall FH, Dive C. Molecular analysis of circulating tumour cells-biology and biomarkers. Nat Rev Clin Oncol. 2014;11:129-44.

56. Schwaederle MC, Patel SP, Husain H, Ikeda M, Lanman RB, Banks KC, Talasaz A, Bazhenova L, Kurzrock R. Utility of Genomic Assessment of Blood-Derived Circulating Tumor DNA (ctDNA) in Patients with Advanced Lung Adenocarcinoma. Clin Cancer Res. 2017;23:5101-11.

57. Bernard V, Kim DU, San Lucas FA, Castillo J, Allenson K, Mulu FC, Stephens BM, Huang J, Semaan A, Guerrero PA, et al. Circulating Nucleic Acids Are Associated With Outcomes of Patients With Pancreatic Cancer. Gastroenterology. 2019;156:108-118.e104.

58. Ossandon MR, Agrawal L, Bernhard EJ, Conley BA, Dey SM, Divi RL, Guan P Lively TG, McKee TC, Sorg BS, Tricoli JV. Circulating Tumor DNA Assays in Clinical Cancer Research. J Natl Cancer Inst. 2018;110:929-34.

59. Chan JYK, Zhen G, Agrawal N: The role of tumor DNA as a diagnostic tool for head and neck squamous cell carcinoma. Semin Cancer Biol. 2018, https://doi.org/10.1016/j.semcancer.2018.07.008

60. Moon DH, Lindsay DP, Hong S, Wang AZ. Clinical indications for, and the future of, circulating tumor cells. Adv Drug Deliv Rev. 2018;125:143-50.

61. Liquid Biopsy Technique May Allow Early Screening. Cancer Discov. 2017;7:1207.

62. Eng C. Circulating DNA biomarkers: a primer for metastatic colorectal cancer? Lancet Oncol. 2015;16:878-9.

63. Friedrich MJ. Going With the Flow: The Promise and Challenge of Liquid Biopsies. Jama. 2017;318:1095-7.

64. Scholer LV, Reinert T, Orntoft MW, Kassentoft CG, Arnadottir SS, Vang S, Nordentoft I, Knudsen M, Lamy P, Andreasen D, et al. Clinical Implications of Monitoring Circulating Tumor DNA in Patients with Colorectal Cancer. Clin Cancer Res. 2017;23:5437-45.

65. Garlan F, Laurent-Puig P, Sefrioui D, Siauve N, Didelot A, Sarafan-Vasseur N, Michel P, Perkins G, Mulot C, Blons H, et al. Early Evaluation of Circulating Tumor DNA as Marker of Therapeutic Efficacy in Metastatic Colorectal Cancer Patients (PLACOL Study). Clin Cancer Res. 2017:23:5416-25.

66. Montagut C, Vidal J, Visa L. KRAS mutations in ctDNA: a promising new biomarker in advanced pancreatic cancer. Ann Oncol. 2018;29:2280-2.

67. Li W, Zhang X, Lu X, You L, Song Y, Luo Z, Zhang J, Nie J, Zheng W, Xu D, et al. 5-Hydroxymethylcytosine signatures in circulating cell-free DNA as diagnostic biomarkers for human cancers. Cell Res. 2017;27:1243-57.

68. Nicolini A, Ferrari P, Duffy MJ. Prognostic and predictive biomarkers in breast cancer: Past, present and future. Semin Cancer Biol. 2018;52:56-73.

69. Cabel L, Proudhon C, Romano E, Girard N, Lantz O, Stern MH, Pierga JY, Bidard FC. Clinical potential of circulating tumour DNA in patients receiving anticancer immunotherapy. Nat Rev Clin Oncol. 2018;15:639-50.

70. Annala M, Vandekerkhove G, Khalaf D, Taavitsainen S, Beja K, Warner EW, Sunderland K, Kollmannsberger C, Eigl BJ, Finch D, et al. Circulating Tumor DNA Genomics Correlate with Resistance to Abiraterone and Enzalutamide in Prostate Cancer. Cancer Discov. 2018;8:444-57.

71. Jin CE, Koo B, Lee TY, Han K, Lim SB, Park IJ, Shin Y. Simple and Low-Cost Sampling of Cell-Free Nucleic Acids from Blood Plasma for Rapid and Sensitive Detection of Circulating Tumor DNA. Adv Sci (Weinh). 2018;5:1800614.

72. Heitzer E, Haque IS, Roberts CES, Speicher MR: Current and future perspectives of liquid biopsies in genomics-driven oncology. Nat Rev Genet. 2018;20:71-88.

73. Siravegna G, Marsoni S, Siena S, Bardelli A. Integrating liquid biopsies into the management of cancer. Nat Rev Clin Oncol. 2017;14:531-48.

74. Tie J, Cohen JD, Wang Y, Li L, Christie M, Simons K, Elsaleh H, Kosmider S, Wong R, Yip D, et al: Serial circulating tumour DNA analysis during multimodality treatment of locally advanced rectal cancer: a prospective biomarker study Gut Epub ahead of print: February 2, 2018. https://doi.org/10.1136/gutjhl-2017-315852.

75. Jia J, Shi Y, Chen L, Lai W, Yan B, Jiang Y, Xiao D, Xi S, Cao Y, Liu S, et al. Decrease in Lymphoid Specific Helicase and 5-hydroxymethylcytosine Is Associated with Metastasis and Genome Instability. Theranostics. 2017;7:3920-32.

76. Xiao D, Huang J, Pan Y, Li H, Fu C, Mao C, Cheng Y, Shi Y, Chen L, Jiang Y, et al. Chromatin Remodeling Factor LSH is Upregulated by the LRP6GSK3beta-E2F1 Axis Linking Reversely with Survival in Gliomas. Theranostics. 2017;7:132-43

77. Jiang Y, Mao C, Yang R, Yan B, Shi Y, Liu X, Lai W, Liu Y, Wang X, Xiao D, et al. EGLN1/c-Myc Induced Lymphoid-Specific Helicase Inhibits Ferroptosis through Lipid Metabolic Gene Expression Changes. Theranostics. 2017;7:3293-305.

78. Mao C, Wang X, Liu Y, Wang M, Yan B, Jiang Y, Shi Y, Shen Y, Liu X, Lai W, et al. A G3BP1-Interacting IncRNA Promotes Ferroptosis and Apoptosis in Cancer via Nuclear Sequestration of p53. Cancer Res. 2018;78:3484-96.
79. Mao C, Wang M, Qian B, Ouyang L, Shi Y, Liu N, Chen L, Xiao D, Wang $X$, Cao $Y$, et al. Aryl hydrocarbon receptor activated by benzo (a) pyrene promotes SMARCA6 expression in NSCLC. Am J Cancer Res. 2018:8:1214-27.

80. He X, Yan B, Liu S, Jia J, Lai W, Xin X, Tang CE, Luo D, Tan T, Jiang Y, et al. Chromatin Remodeling Factor LSH Drives Cancer Progression by Suppressing the Activity of Fumarate Hydratase. Cancer Res. 2016;76:5743-55.

81. Schagdarsurengin U, Gimm O, Hoang-Vu C, Dralle H, Pfeifer GP, Dammann $R$. Frequent epigenetic silencing of the CPG island promoter of RASSF1A in thyroid carcinoma. Cancer Res. 2002;62:3698-701.

82. Gai W, Ji L, Lam WKJ, Sun K, Jiang P, Chan AWH, Wong J, Lai PBS, Ng SSM, Ma BBY, et al. Liver- and Colon-Specific DNA Methylation Markers in Plasma for Investigation of Colorectal Cancers with or without Liver Metastases. Clin Chem 2018;64:1239-49.

83. Weiss G, Schlegel A, Kottwitz D, Konig T, Tetzner R. Validation of the SHOX2/PTGER4 DNA Methylation Marker Panel for Plasma-Based Discrimination between Patients with Malignant and Nonmalignant Lung Disease. J Thorac Oncol. 2017;12:77-84.

84. Reis IM, Ramachandran K, Speer C, Gordian E, Singal R. Serum GADD45a methylation is a useful biomarker to distinguish benign vs malignant prostate disease. Br J Cancer. 2015:113:460-8.

85. Garrigou S, Perkins G, Garlan F, Normand C, Didelot A, Le Corre D, Peyvandi S, Mulot C, Niarra R, Aucouturier P, et al. A Study of Hypermethylated Circulating Tumor DNA as a Universal Colorectal Cancer Biomarker. Clin Chem. 2016;62:1129-39.

86. Bachet JB, Bouche O, Taieb J, Dubreuil O, Garcia ML, Meurisse A, Normand C, Gornet JM, Artru P, Louafi S, et al. RAS mutation analysis in circulating tumor DNA from patients with metastatic colorectal cancer: the AGEO RASANC prospective multicenter study. Ann Oncol. 2018:29:1211-9.

87. Jin Z, Olaru A, Yang J, Sato F, Cheng Y, Kan T, Mori Y, Mantzur C, Paun B, Hamilton JP, et al. Hypermethylation of tachykinin-1 is a potential biomarker in human esophageal cancer. Clin Cancer Res. 2007;13:6293-300.

88. Oussalah A, Rischer S, Bensenane M, Conroy G, Filhine-Tresarrieu P, Debard R, Forest-Tramoy D, Josse T, Reinicke D, Garcia M, et al. Plasma mSEPT9: A Novel Circulating Cell-free DNA-Based Epigenetic Biomarker to Diagnose Hepatocellular Carcinoma. EBioMedicine. 2018;30:138-47.

89. Schrock A, Leisse A, de Vos L, Gevensleben H, Droge F, Franzen A, Wachendorfer M, Schrock F, Ellinger J, Teschke M, et al. Free-Circulating Methylated DNA in Blood for Diagnosis, Staging, Prognosis, and Monitoring of Head and Neck Squamous Cell Carcinoma Patients: An Observational Prospective Cohort Study. Clin Chem. 2017;63:1288-96.

90. Ramirez JL, Rosell R, Taron M, Sanchez-Ronco M, Alberola V, de Las PR, Sanchez JM, Moran T, Camps C, Massuti B, et al. 14-3-3sigma methylation in pretreatment serum circulating DNA of cisplatin-plus-gemcitabine-treated advanced non-small-cell lung cancer patients predicts survival: The Spanish Lung Cancer Group. J Clin Oncol. 2005;23:9105-12.

91. Barault L, Amatu A, Bleeker FE, Moutinho C, Falcomata C, Fiano V, Cassingena A, Siravegna G, Milione $M$, Cassoni $P$, et al. Digital PCR quantification of MGMT methylation refines prediction of clinical benefit from alkylating agents in glioblastoma and metastatic colorectal cancer. Ann Oncol. 2015;26:1994-9.

92. Visvanathan K, Fackler MS, Zhang Z, Lopez-Bujanda ZA, Jeter SC, Sokoll LJ, Garrett-Mayer E, Cope LM, Umbricht CB, Euhus DM, et al. Monitoring of Serum DNA Methylation as an Early Independent Marker of Response and Survival in Metastatic Breast Cancer: TBCRC 005 Prospective Biomarker Study. J Clin Oncol. 2017;35:751-8.

93. Widschwendter M, Zikan M, Wahl B, Lempiainen H, Paprotka T, Evans I, Jones A, Ghazali S, Reisel D, Eichner J, et al. The potential of circulating tumor DNA methylation analysis for the early detection and management of ovarian cancer. Genome Med. 2017;9:116.

94. Ooki A, Maleki Z, Tsay JJ, Goparaju C, Brait M, Turaga N, Nam HS, Rom WN, Pass Hl, Sidransky D, et al. A Panel of Novel Detection and Prognostic Methylated DNA Markers in Primary Non-Small Cell Lung Cancer and Serum DNA. Clin Cancer Res. 2017;23:7141-52.

95. Guo S, Diep D, Plongthongkum N, Fung HL, Zhang K, Zhang K. Identification of methylation haplotype blocks aids in deconvolution of heterogeneous tissue samples and tumor tissue-of-origin mapping from plasma DNA. Nat Genet. 2017;49:635-42.

96. Branco MR, Ficz G, Reik W. Uncovering the role of 5-hydroxymethylcytosine in the epigenome. Nat Rev Genet. 2011;13:7-13. 
97. Sun K, Jiang P, Chan KC, Wong J, Cheng YK, Liang RH, Chan WK, Ma ES, Chan SL, Cheng SH, et al. Plasma DNA tissue mapping by genome-wide methylation sequencing for noninvasive prenatal, cancer, and transplantation assessments. Proc Natl Acad Sci U S A. 2015;112:E5503-12.

98. Zhang J, Han X, Gao C, Xing Y, Qi Z, Liu R, Wang Y, Zhang X, Yang YG, Li X, et al. 5-Hydroxymethylome in Circulating Cell-free DNA as A Potential Biomarker for Non-small-cell Lung Cancer. Genomics Proteomics Bioinformatics. 2018;16:187-99.

99. Charlton J, Williams RD, Weeks M, Sebire NJ, Popov S, Vujanic G, Mifsud W, Alcaide-German M, Butcher LM, Beck S, Pritchard-Jones K. Methylome analysis identifies a Wilms tumor epigenetic biomarker detectable in blood. Genome Biol. 2014;15:434.

100. Bettegowda C, Sausen M, Leary RJ, Kinde I, Wang Y, Agrawal N, Bartlett BR, Wang $H$, Luber B, Alani RM, et al. Detection of circulating tumor DNA in early- and late-stage human malignancies. Sci Transl Med. 2014;6:224ra224.

101. Azad AA, Volik SV, Wyatt AW, Haegert A, Le Bihan S, Bell RH, Anderson SA, McConeghy B, Shukin R, Bazov J, et al. Androgen Receptor Gene Aberrations in Circulating Cell-Free DNA: Biomarkers of Therapeutic Resistance in CastrationResistant Prostate Cancer. Clin Cancer Res. 2015;21:2315-24.

102. Thierry AR, El Messaoudi S, Gahan PB, Anker P, Stroun M. Origins, structures, and functions of circulating DNA in oncology. Cancer Metastasis Rev. 2016; 35:347-76.

103. Harris FR, Kovtun IV, Smadbeck J, Multinu F, Jatoi A, Kosari F, Kalli KR Murphy SJ, Halling GC, Johnson SH, et al. Quantification of Somatic Chromosomal Rearrangements in Circulating Cell-Free DNA from Ovarian Cancers. Sci Rep. 2016;6:29831.

104. Pietrasz D, Pecuchet N, Garlan F, Didelot A, Dubreuil O, Doat S, Imbert-Bismut F, Karoui M, Vaillant JC, Taly V, et al. Plasma Circulating Tumor DNA in Pancreatic Cancer Patients Is a Prognostic Marker. Clin Cancer Res. 2017;23:116-23.

105. Sausen M, Phallen J, Adleff V, Jones S, Leary RJ, Barrett MT, Anagnostou V, Parpart-Li S, Murphy D, Kay Li Q, et al. Clinical implications of genomic alterations in the tumour and circulation of pancreatic cancer patients. Nat Commun. 2015; 6:7686.

106. Reinert T, Scholer LV, Thomsen $R$, Tobiasen H, Vang S, Nordentoft I, Lamy P, Kannerup AS, Mortensen FV, Stribolt K, et al. Analysis of circulating tumour DNA to monitor disease burden following colorectal cancer surgery. Gut. 2016;65:625-34.

107. Tie J, Wang Y, Tomasetti C, Li L, Springer S, Kinde I, Silliman N, Tacey M, Wong HL, Christie M, et al. Circulating tumor DNA analysis detects minimal residual disease and predicts recurrence in patients with stage II colon cancer. Sci Transl Med. 2016;8:346ra392.

108. Guo N, Lou F, Ma Y, Li J, Yang B, Chen W, Ye H, Zhang JB, Zhao MY, Wu WJ, et al. Circulating tumor DNA detection in lung cancer patients before and after surgery. Sci Rep. 2016;6:33519.

109. Husain H, Melnikova VO, Kosco K, Woodward B, More S, Pingle SC, Weihe E, Park BH, Tewari M, Erlander MG, et al. Monitoring Daily Dynamics of Early Tumor Response to Targeted Therapy by Detecting Circulating Tumor DNA in Urine. Clin Cancer Res. 2017:23:4716-23.

110. Wan R, Wang Z, Lee JJ, Wang S, Li Q, Tang F, Wang J, Sun Y, Bai H, Wang D, et al. Comprehensive Analysis of the Discordance of EGFR Mutation Status between Tumor Tissues and Matched Circulating Tumor DNA in Advanced Non-Small Cell Lung Cancer. J Thorac Oncol. 2017;12:1376-87.

111. Huang Z, Wang Z, Bai H, Wu M, An T, Zhao J, Yang L, Duan J, Zhuo M, Wang $Y$, et al. The detection of EGFR mutation status in plasma is reproducible and can dynamically predict the efficacy of EGFR-TKI. Thorac Cancer. 2012;3:334-40.

112. Zheng $D$, Ye $X$, Zhang MZ, Sun $Y$, Wang JY, Ni J, Zhang HP, Zhang L, Luo J, Zhang J, et al. Plasma EGFR T790M ctDNA status is associated with clinical outcome in advanced NSCLC patients with acquired EGFR-TKI resistance. Sci Rep. 2016:6:20913.

113. Nygaard AD, Garm Spindler KL, Pallisgaard N, Andersen RF, Jakobsen A. The prognostic value of KRAS mutated plasma DNA in advanced non-small cell lung cancer. Lung Cancer. 2013;79:312-7.

114. Iwama E, Sakai K, Azuma K, Harada T, Harada D, Nosaki K, Hotta K, Ohyanagi F, Kurata T, Fukuhara T, et al. Monitoring of somatic mutations in circulating cell-free DNA by digital PCR and next-generation sequencing during afatinib treatment in patients with lung adenocarcinoma positive for EGFR activating mutations. Ann Oncol. 2017;28:136-41.

115. Jamal-Hanjani M, Wilson GA, Horswell S, Mitter R, Sakarya O, Constantin T, Salari R, Kirkizlar E, Sigurjonsson S, Pelham R, et al. Detection of ubiquitous and heterogeneous mutations in cell-free DNA from patients with earlystage non-small-cell lung cancer. Ann Oncol. 2016;27:862-7.
116. Quigley D, Alumkal JJ, Wyatt AW, Kothari V, Foye A, Lloyd P, Aggarwal R, Kim W, Lu E, Schwartzman J, et al. Analysis of Circulating Cell-Free DNA Identifies Multiclonal Heterogeneity of BRCA2 Reversion Mutations Associated with Resistance to PARP Inhibitors. Cancer Discov. 2017;7:999-1005.

117. Annala M, Struss WJ, Warner EW, Beja K, Vandekerkhove G, Wong A, Khalaf D, Seppala IL, So A, Lo G, et al. Treatment Outcomes and Tumor Loss of Heterozygosity in Germline DNA Repair-deficient Prostate Cancer. Eur Urol. 2017;72:34-42.

118. Lallous N, Volik SV, Awrey S, Leblanc E, Tse R, Murillo J, Singh K, Azad AA, Wyatt AW, LeBihan $S$, et al. Functional analysis of androgen receptor mutations that confer anti-androgen resistance identified in circulating cell-free DNA from prostate cancer patients. Genome Biol. 2016;17:10.

119. Conteduca V, Wetterskog D, Sharabiani MTA, Grande E, Fernandez-Perez MP, Jayaram A, Salvi S, Castellano D, Romanel A, Lolli C, et al. Androgen receptor gene status in plasma DNA associates with worse outcome on enzalutamide or abiraterone for castration-resistant prostate cancer: a multiinstitution correlative biomarker study. Ann Oncol. 2017;28:1508-16.

120. Wyatt AW, Azad AA, Volik SV, Annala M, Beja K, McConeghy B, Haegert A, Warner EW, Mo F, Brahmbhatt S, et al. Genomic Alterations in Cell-Free DNA and Enzalutamide Resistance in Castration-Resistant Prostate Cancer. JAMA Oncol. 2016;2:1598-606

121. Goodall J, Mateo J, Yuan W, Mossop H, Porta N, Miranda S, Perez-Lopez R, Dolling D, Robinson DR, Sandhu S, et al. Circulating Cell-Free DNA to Guide Prostate Cancer Treatment with PARP Inhibition. Cancer Discov. 2017;7:1006-17.

122. O'Leary B, Hrebien S, Morden JP, Beaney M, Fribbens C, Huang X, Liu Y, Bartlett $\mathrm{CH}$, Koehler M, Cristofanilli M, et al. Early circulating tumor DNA dynamics and clonal selection with palbociclib and fulvestrant for breast cancer. Nat Commun. 2018;9:896.

123. Schiavon G, Hrebien S, Garcia-Murillas I, Cutts RJ, Pearson A, Tarazona N Fenwick K, Kozarewa I, Lopez-Knowles E, Ribas R, et al. Analysis of ESR1 mutation in circulating tumor DNA demonstrates evolution during therapy for metastatic breast cancer. Sci Transl Med. 2015;7:313ra182.

124. Goyal L, Saha SK, Liu LY, Siravegna G, Leshchiner I, Ahronian LG, Lennerz JK, Vu P, Deshpande V, Kambadakone A, et al. Polyclonal Secondary FGFR2 Mutations Drive Acquired Resistance to FGFR Inhibition in Patients with FGFR2 Fusion-Positive Cholangiocarcinoma. Cancer Discov. 2017;7:252-63.

125. Parkinson CA, Gale D, Piskorz AM, Biggs H, Hodgkin C, Addley H, Freeman S, Moyle P, Sala E, Sayal K, et al. Exploratory Analysis of TP53 Mutations in Circulating Tumour DNA as Biomarkers of Treatment Response for Patients with Relapsed High-Grade Serous Ovarian Carcinoma: A Retrospective Study. PLoS Med. 2016;13:e1002198.

126. Russo M, Misale S, Wei G, Siravegna G, Crisafulli G, Lazzari L, Corti G, Rospo G, Novara L, Mussolin B, et al. Acquired Resistance to the TRK Inhibitor Entrectinib in Colorectal Cancer. Cancer Discov. 2016;6:36-44.

127. Russo M, Siravegna G, Blaszkowsky LS, Corti G, Crisafulli G, Ahronian LG Mussolin B, Kwak EL, Buscarino M, Lazzari L, et al. Tumor Heterogeneity and Lesion-Specific Response to Targeted Therapy in Colorectal Cancer. Cancer Discov. 2016:6:147-53

128. Kruger S, Heinemann V, Ross C, Diehl F, Nagel D, Ormanns S, Liebmann S, Prinz-Bravin I, Westphalen CB, Haas M, et al. Repeated mutKRAS ctDNA measurements represent a novel and promising tool for early response prediction and therapy monitoring in advanced pancreatic cancer. Ann Oncol. 2018;29:2348-55.

129. Tabernero J, Lenz HJ, Siena S, Sobrero A, Falcone A, Ychou M, Humblet $Y$, Bouche $\mathrm{O}$, Mineur L, Barone $\mathrm{C}$, et al. Analysis of circulating DNA and protein biomarkers to predict the clinical activity of regorafenib and assess prognosis in patients with metastatic colorectal cancer: a retrospective, exploratory analysis of the CORRECT trial. Lancet Oncol. 2015;16:937-48.

130. Yi HM, Yi H, Zhu JF, Xiao T, Lu SS, Guan YJ, Xiao ZQ. A five-variable signature predicts radioresistance and prognosis in nasopharyngeal carcinoma patients receiving radical radiotherapy. Tumour Biol. 2016;37:2941-9.

131. Hu W, Yang Y, Zhang L, Yin J, Huang J, Huang L, Gu H, Jiang G, Fang J. Post surgery circulating free tumor DNA is a predictive biomarker for relapse of lung cancer. Cancer Med. 2017;6:962-74.

132. Pecuchet N, Zonta E, Didelot A, Combe P, Thibault C, Gibault L, Lours $C$, Rozenholc $Y$, Taly $V$, Laurent-Puig P, et al. Base-Position Error Rate Analysis of Next-Generation Sequencing Applied to Circulating Tumor DNA in Non-Small Cell Lung Cancer: A Prospective Study. PLoS Med. 2016;13:e1002199. 
133. Cai ZX, Chen G, Zeng YY, Dong XQ, Lin MJ, Huang XH, Zhang D, Liu XL, Liu JF. Circulating tumor DNA profiling reveals clonal evolution and real-time disease progression in advanced hepatocellular carcinoma. Int J Cancer. 2017;141:977-85.

134. Yi X, Ma J, Guan Y, Chen R, Yang L, Xia X. The feasibility of using mutation detection in ctDNA to assess tumor dynamics. Int J Cancer. 2017;140:2642-7.

135. Shaw JA, Guttery DS, Hills A, Fernandez-Garcia D, Page K, Rosales BM, Goddard KS, Hastings RK, Luo J, Ogle O, et al. Mutation Analysis of Cell-Free DNA and Single Circulating Tumor Cells in Metastatic Breast Cancer Patients with High Circulating Tumor Cell Counts. Clin Cancer Res. 2017;23:88-96.

136. Abbosh C, Birkbak NJ, Wilson GA, Jamal-Hanjani M, Constantin T, Salari R, Le Quesne J, Moore DA, Veeriah S, Rosenthal R, et al. Phylogenetic ctDNA analysis depicts early-stage lung cancer evolution. Nature. 2017;545:446-51.

137. Christensen E, Birkenkamp-Demtroder K, Nordentoft I, Hoyer S, van der Keur K, van Kessel K, Zwarthoff E, Agerbaek M, Orntoft TF, Jensen JB, Dyrskjot L. Liquid Biopsy Analysis of FGFR3 and PIK3CA Hotspot Mutations for Disease Surveillance in Bladder Cancer. Eur Urol. 2017;71:961-9.

138. Olsson E, Winter C, George A, Chen Y, Howlin J, Tang MH, Dahlgren M, Schulz R, Grabau D, van Westen D, et al. Serial monitoring of circulating tumor DNA in patients with primary breast cancer for detection of occult metastatic disease. EMBO Mol Med. 2015;7:1034-47.

139. Wyatt AW, Annala M, Aggarwal R, Beja K, Feng F, Youngren J, Foye A, Lloyd P, Nykter M, Beer TM, et al: Concordance of Circulating Tumor DNA and Matched Metastatic Tissue Biopsy in Prostate Cancer. J Natl Cancer Inst. 2017;109:78-86.

140. Liberti MV, Locasale JW. The Warburg Effect: How Does it Benefit Cancer Cells? Trends Biochem Sci. 2016;41:211-8.

141. Ma W, Jia J, Wang S, Bai W, Yi J, Bai M, Quan Z, Yin Z, Fan D, Wang J, Han G. The prognostic value of 18F-FDG PET/CT for hepatocellular carcinoma treated with transarterial chemoembolization (TACE). Theranostics. 2014;4:736-44.

142. Patel D, Mehta A, Nilubol N, Dieckmann W, Pacak K, Kebebew E. Total 18FFDG PET/CT Metabolic Tumor Volume Is Associated With Postoperative Biochemical Response in Patients With Metastatic Pheochromocytomas and Paragangliomas. Ann Surg. 2016;263:582-7.

143. de Jong EE, van Elmpt W, Leijenaar RT, Hoekstra OS, Groen HJ, Smit EF, Boellaard R, van der Noort V, Troost EG, Lambin P. Dingemans AC: [18F] FDG PET/CT-based response assessment of stage IV non-small cell lung cancer treated with paclitaxel-carboplatin-bevacizumab with or without nitroglycerin patches. Eur J Nucl Med Mol Imaging. 2017;44:8-16.

144. Goense L, Ruurda JP, Carter BW, Fang P, Ho L, Meijer GJ, van Hillegersberg R, Hofstetter WL, Lin SH. Prediction and diagnosis of interval metastasis after neoadjuvant chemoradiotherapy for oesophageal cancer using (18) F-FDG PET/CT. Eur J Nucl Med Mol Imaging. 2018;45:1742-51.

145. Romero-Lluch AR, Cuenca-Cuenca Jl, Guerrero-Vazquez R, Martinez-Ortega AJ, Tirado-Hospital JL, Borrego-Dorado I, Navarro-Gonzalez E. Diagnostic utility of PET/CT with (18) F-DOPA and (18) F-FDG in persistent or recurrent medullary thyroid carcinoma: the importance of calcitonin and carcinoembryonic antigen cutoff. Eur J Nucl Med Mol Imaging. 2017:44:2004-13.

146. Nygaard AD, Holdgaard PC, Spindler KL, Pallisgaard N, Jakobsen A. The correlation between cell-free DNA and tumour burden was estimated by PET/CT in patients with advanced NSCLC. Br J Cancer. 2014;110:363-8.

147. Winther-Larsen A, Demuth C, Fledelius J, Madsen AT, Hjorthaug K, Meldgaard P, Sorensen BS. Correlation between circulating mutant DNA and metabolic tumour burden in advanced non-small cell lung cancer patients. Br J Cancer. 2017;117:704-9.

148. Dong T, Liu Z, Xuan Q, Wang Z, Ma W, Zhang Q. Tumor LDH-A expression and serum LDH status are two metabolic predictors for triple negative breast cancer brain metastasis. Sci Rep. 2017;7:6069.

149. Faloppi L, Del Prete M, Casadei Gardini A, Santini D, Silvestris N, Bianconi M, Giampieri R, Valgiusti M, Brunetti O, Bittoni A, et al. The correlation between LDH serum levels and clinical outcome in advanced biliary tract cancer patients treated with first line chemotherapy. Sci Rep. 2016;6:24136.

150. Marmorino F, Salvatore L, Barbara C, Allegrini G, Antonuzzo L, Masi G, Loupakis F, Borelli B, Chiara S, Banzi MC, et al. Serum LDH predicts benefit from bevacizumab beyond progression in metastatic colorectal cancer. $\mathrm{Br}$ J Cancer. 2017;116:318-23.

151. Roseweir AK, Clark J, MCSorley ST, van Wyk HC, Quinn JA, Horgan PG, McMillan DC, Park JH, Edwards J: The association between markers of tumor cell metabolism, the tumor microenvironment and outcomes in patients with colorectal cancer. Int J Cancer 2018. https://doi.org/10.1002/ijc.32045.
152. Tsao SC, Weiss J, Hudson C, Christophi C, Cebon J, Behren A, Dobrovic A. Monitoring response to therapy in melanoma by quantifying circulating tumour DNA with droplet digital PCR for BRAF and NRAS mutations. Sci Rep. 2015;5:11198.

153. Chang GA, Tadepalli JS, Shao Y, Zhang Y, Weiss S, Robinson E, Spittle C, Furtado M, Shelton DN, Karlin-Neumann G, et al. Sensitivity of plasma BRAFmutant and NRASmutant cell-free DNA assays to detect metastatic melanoma in patients with low RECIST scores and non-RECIST disease progression. Mol Oncol. 2016;10:157-65.

154. Berridge MV, Dong L, Neuzil J. Mitochondrial DNA in Tumor Initiation, Progression, and Metastasis: Role of Horizontal mtDNA Transfer. Cancer Res. 2015;75:3203-8.

155. Reznik E, Miller ML, Senbabaoglu Y, Riaz N, Sarungbam J, Tickoo SK, AlAhmadie HA, Lee W, Seshan VE, Hakimi AA, Sander C: Mitochondrial DNA copy number variation across human cancers. Elife 2016;5:e10769.

156. Yuzefovych LV, Kahn AG, Schuler MA, Eide L, Arora R, Wilson GL, Tan M, Rachek LI. Mitochondrial DNA Repair through OGG1 Activity Attenuates Breast Cancer Progression and Metastasis. Cancer Res. 2016;76:30-4.

157. Cormio A, Sanguedolce F, Musicco C, Pesce V, Calo G, Bufo P, Carrieri G, Cormio L. Mitochondrial dysfunctions in bladder cancer: Exploring their role as disease markers and potential therapeutic targets. Crit Rev Oncol Hematol. 2017;117:67-72.

158. Truksa J, Dong LF, Rohlena J, Stursa J, Vondrusova M, Goodwin J, Nguyen M, Kluckova K, Rychtarcikova Z, Lettlova S, et al. Mitochondrially targeted vitamin E succinate modulates expression of mitochondrial DNA transcripts and mitochondrial biogenesis. Antioxid Redox Signal. 2015;22:883-900.

159. Hu P, Wu T, Fan W, Chen L, Liu Y, Ni D, Bu W, Shi J. Near infrared-assisted Fenton reaction for tumor-specific and mitochondrial DNA-targeted photochemotherapy. Biomaterials. 2017;141:86-95.

160. Szczesny B, Marcatti M, Zatarain JR, Druzhyna N, Wiktorowicz JE, Nagy P, Hellmich MR, Szabo C. Inhibition of hydrogen sulfide biosynthesis sensitizes lung adenocarcinoma to chemotherapeutic drugs by inhibiting mitochondrial DNA repair and suppressing cellular bioenergetics. Sci Rep. 2016;6:36125.

161. Weerts MJA, Timmermans EC, van de Stolpe A, Vossen R, Anvar SY, Foekens JA, Sleijfer S, Martens JWM. Tumor-Specific Mitochondrial DNA Variants Are Rarely Detected in Cell-Free DNA. Neoplasia. 2018;20:687-96.

162. Mair R, Mouliere F, Smith CG, Chandrananda D, Gale D, Marass F, Tsui DWY, Massie CE, Wright AJ, Watts C, et al. Measurement of Plasma Cell-Free Mitochondrial Tumor DNA Improves Detection of Glioblastoma in PatientDerived Orthotopic Xenograft Models. Cancer Res. 2019;79:220-30.

163. Mehra N, Penning M, Maas J, van Daal N, Giles RH, Voest EE. Circulating mitochondrial nucleic acids have prognostic value for survival in patients with advanced prostate cancer. Clin Cancer Res. 2007;13:421-6.

164. Zhang P, Samuels DC, Lehmann B, Stricker T, Pietenpol J, Shyr Y, Guo Y. Mitochondria sequence mapping strategies and practicability of mitochondria variant detection from exome and RNA sequencing data. Brief Bioinform. 2016;17:224-32.

165. Izumchenko E, Chang X, Brait M, Fertig E, Kagohara LT, Bedi A, Marchionni L, Agrawal N, Ravi R, Jones S, et al: Targeted sequencing reveals clonal genetic changes in the progression of early lung neoplasms and paired circulating DNA. Nature Communications 2015, 6:8258-8258.

166. Boshuizen J, Koopman LA, Krijgsman O, Shahrabi A, van den Heuvel EG, Ligtenberg MA, Vredevoogd DW, Kemper K, Kuilman T, Song J-Y, et al. Cooperative targeting of melanoma heterogeneity with an $\mathrm{AXL}$ antibody-drug conjugate and BRAF/MEK inhibitors. Nature Medicine. 2018;24:203-12

167. Lohr JG, Stojanov P, Carter SL, Cruz-Gordillo P, Lawrence MS, Auclair D, Sougnez C, Knoechel B, Gould J, Saksena G, et al. Widespread genetic heterogeneity in multiple myeloma: Implications for targeted therapy. Cancer Cell. 2014;25:91-101.

168. Mithraprabhu S, Khong T, Ramachandran M, Chow A, Klarica D, Mai L, Walsh $S$, Broemeling D, Marziali A, Wiggin M, et al. Circulating tumour DNA analysis demonstrates spatial mutational heterogeneity that coincides with disease relapse in myeloma. Leukemia. 2017;31:1695-705.

169. Imamura F, Uchida J, Kukita Y, Kumagai T, Nishino K, Inoue T, Kimura M, Oba S, Kato K. Monitoring of treatment responses and clonal evolution of tumor cells by circulating tumor DNA of heterogeneous mutant EGFR genes in lung cancer. Lung Cancer. 2016;94:68-73.

170. Spoerke JM, Gendreau S, Walter K, Qiu J, Wilson TR, Savage H, Aimi J, Derynck MK, Chen M, Chan IT, et al: Heterogeneity and clinical significance of ESR1 mutations in ER-positive metastatic breast cancer patients receiving fulvestrant. Nature Communications 2016, 7:11579-11579. 
171. Hazar-Rethinam M, Kleyman M, Han GC, Liu D, Ahronian LG, Shahzade HA Chen L, Parikh AR, Allen JN, Clark JW, et al. Convergent Therapeutic Strategies to Overcome the Heterogeneity of Acquired Resistance in BRAFV600E Colorectal Cancer. Cancer discovery. 2018:8:417-27.

172. Casasent AK, Schalck A, Gao R, Sei E, Long A, Pangburn W, Casasent T, Meric-Bernstam F, Edgerton ME, Navin NE. Multiclonal Invasion in Breast Tumors Identified by Topographic Single Cell Sequencing. Cell. 2018;172: 205-217.e212.

173. Lebofsky R, Decraene C, Bernard V, Kamal M, Blin A, Leroy Q, Rio Frio T, Pierron G, Callens C, Bieche I, et al. Circulating tumor DNA as a non-invasive substitute to metastasis biopsy for tumor genotyping and personalized medicine in a prospective trial across all tumor types. Mol Oncol. 2015;9:783-90.

174. Kwak EL, Ahronian LG, Siravegna G, Mussolin B, Borger DR, Godfrey JT, Jessop NA, Clark JW, Blaszkowsky LS, Ryan DP, et al. Molecular Heterogeneity and Receptor Coamplification Drive Resistance to Targeted Therapy in MET-Amplified Esophagogastric Cancer. Cancer discovery. 2015;5: $1271-81$.

175. Thress KS, Brant R, Carr TH, Dearden S, Jenkins S, Brown H, Hammett T, Cantarini M, Barrett JC. EGFR mutation detection in ctDNA from NSCLC patient plasma: A cross-platform comparison of leading technologies to support the clinical development of AZD9291. Lung Cancer. 2015;90:509-15.

176. Wang W, Song Z, Zhang Y. A Comparison of ddPCR and ARMS for detecting EGFR T790M status in ctDNA from advanced NSCLC patients with acquired EGFR-TKI resistance. Cancer Medicine. 2017;6:154-62.

177. Wang Z, Cheng Y, An T, Gao H, Wang K, Zhou Q, Hu Y, Song Y, Ding C, Peng $F$, et al. Detection of EGFR mutations in plasma circulating tumour DNA as a selection criterion for first-line gefitinib treatment in patients with advanced lung adenocarcinoma (BENEFIT): a phase 2, single-arm, multicentre clinical trial. The Lancet Respiratory Medicine. 2018;2600:1-10.

178. Carneiro BA, Pamarthy S, Shah AN, Sagar V, Unno K, Han H, Yang XJ, Costa RB, Nagy RJ, Lanman RB, et al. Anaplastic lymphoma kinase mutation (ALK F1174C) in small cell carcinoma of the prostate and molecular response to alectinib. Clinical Cancer Research. 2018; clincanres.0332.2018-clincanres. 0332.2018.

179. Lim HY, Merle P, Weiss KH, Yau TCC, Ross P, Mazzaferro V, Blanc J-F, Ma YT, Yen C-J, Kocsis J, et al. Phase II Studies with Refametinib or Refametinib plus Sorafenib in Patients with $<\mathrm{i}>\mathrm{RAS}</ \mathrm{i}>$-mutated Hepatocellular Carcinoma. Clinical Cancer Research. 2018; clincanres.3588.2017-clincanres.3588.2017.

180. Schwaederle M, Chattopadhyay R, Kato S, Fanta PT, Banks KC, Choi IS, Piccioni DE, Ikeda S, Talasaz AA, Lanman RB, et al. Genomic alterations in circulating tumor DNA from diverse cancer patients identified by nextgeneration sequencing. Cancer Research. 2017;77:5419-27.

181. Janku F, Zhang S, Waters J, Liu L, Huang HJ, Subbiah V, Hong DS, Karp DD, Fu S, Cai $X$, et al. Development and validation of an ultradeep nextgeneration sequencing assay for testing of plasma cell-free DNA from patients with advanced cancer. Clinical Cancer Research. 2017;23:5648-56.

182. Renfro LA, Mallick H, An MW, Sargent DJ, Mandrekar SJ. Clinical trial designs incorporating predictive biomarkers. Cancer Treat Rev. 2016;43:74-82.

183. Neumann MHD, Bender S, Krahn T. Schlange T: ctDNA and CTCs in Liquid Biopsy - Current Status and Where We Need to Progress. Computational and Structural Biotechnology Journal. 2018;16:190-5.

184. Rubicz R, Zhao S, Wright JL, Coleman I, Grasso C, Geybels MS, Leonardson A, Kolb S, April C, Bibikova M, et al. Gene expression panel predicts metastatic-lethal prostate cancer outcomes in men diagnosed with clinically localized prostate cancer. Molecular oncology. 2017;11:140-50.

185. Kang Q, Henry NL, Paoletti C, Jiang H, Vats P, Chinnaiyan AM, Hayes DF, Merajver SD, Rae JM, Tewari M. Comparative analysis of circulating tumor DNA stability In K3EDTA, Streck, and CellSave blood collection tubes. Clinical Biochemistry. 2016:49:1354-60.

186. Sorber L, Zwaenepoel K, Deschoolmeester V, Roeyen G, Lardon F, Rolfo C, Pauwels P. A Comparison of Cell-Free DNA Isolation Kits: Isolation and Quantification of Cell-Free DNA in Plasma. Journal of Molecular Diagnostics. 2017;19:162-8.

187. Risberg B, Tsui DWY, Biggs H, Ruiz-Valdepenas Martin de Almagro A, Dawson SJ, Hodgkin C, Jones L, Parkinson C, Piskorz A, Marass F, et al. Effects of Collection and Processing Procedures on Plasma Circulating Cell-Free DNA from Cancer Patients. Journal of Molecular Diagnostics. 2018;20:883-92.

188. Parpart-Li S, Bartlett B, Popoli M, Adleff V, Tucker L, Steinberg R, Georgiadis A, Phallen J, Brahmer J, Azad N, et al. The effect of preservative and temperature on the analysis of circulating tumor DNA. Clinical Cancer Research. 2017;23:2471-7.
189. Bartels S, Persing S, Hasemeier B, Schipper E, Kreipee H, Lehmann U. Molecular Analysis of Circulating Cell-Free DNA from Lung Cancer Patients in Routine Laboratory Practice: A Cross-Platform Comparison of Three Different Molecular Methods for Mutation Detection; 2017. p. 722-32.

190. Lupo M, Guttler R, Geck Z, Tonozzi TR, Kammesheidt A, Braunstein GD. Is Measurement of Circulating Tumor Dna of Diagnostic Use in Patients With Thyroid Nodules? Endocrine Practice. 2018;24:453-9.

191. Mead R, Duku M, Bhandari P, Cree IA. Circulating tumour markers can define patients with normal colons, benign polyps, and cancers. British Journal of Cancer. 2011;105:239-45.

192. Myint NNM, Verma AM, Fernandez-Garcia D, Sarmah P, Tarpey PS, Al-Aqbi SS, Cai H, Trigg R, West K, Howells LM, et al: Circulating tumor DNA in patients with colorectal adenomas: assessment of detectability and genetic heterogeneity. Cell Death Dis. 2018;9:894.

193. Alix-Panabières C, Pantel K. Clinical applications of circulating tumor cells and circulating tumor DNA as liquid biopsy. Cancer Discovery. 2016;6:479-91.

194. Jaiswal S, Fontanillas P, Flannick J, Manning A, Grauman PV, Mar BG, Lindsley RC, Mermel CH, Burtt N, Chavez A, et al. Age-Related Clonal Hematopoiesis Associated with Adverse Outcomes. New England Journal of Medicine. 2014;371:2488-98

195. Merker JD, Oxnard GR, Compton C, Diehn M, Hurley P, Lazar AJ, Lindeman N, Lockwood CM, Rai AJ, Schilsky RL, et al: Circulating tumor DNA analysis in patients with cancer: American society of clinical oncology and college of American pathologists joint review. vol. 142. pp. 1242-12532018:1242-1253.

196. Schwarzenbach H, Hoon DSB, Pantel K. Cell-free nucleic acids as biomarkers in cancer patients. Nature Reviews Cancer. 2011;11:426-37.

197. Gabriel E, Bagaria SP. Assessing the Impact of Circulating Tumor DNA (ctDNA) in Patients With Colorectal Cancer: Separating Fact From Fiction. Frontiers in Oncology. 2018;8:1-7.

198. Fiala C, Diamandis EP. Utility of circulating tumor DNA in cancer diagnostics with emphasis on early detection. BMC Medicine. 2018;16:1-10.

199. Abbosh C, Birkbak NJ, Swanton C: Early stage NSCLC - challenges to implementing ctDNA-based screening and MRD detection. Nat Rev Clin Oncol. 2018;15:577-586.

200. Krug AK, Enderle D, Karlovich C, Priewasser T, Bentink S, Spiel A, Brinkmann K, Emenegger J, Grimm DG, Castellanos-Rizaldos E, et al. Improved EGFR mutation detection using combined exosomal RNA and circulating tumor DNA in NSCLC patient plasma. Ann Oncol. 2018;29:700-6.

Ready to submit your research? Choose BMC and benefit from:

- fast, convenient online submission

- thorough peer review by experienced researchers in your field

- rapid publication on acceptance

- support for research data, including large and complex data types

- gold Open Access which fosters wider collaboration and increased citations

- maximum visibility for your research: over $100 \mathrm{M}$ website views per year

At BMC, research is always in progress.

Learn more biomedcentral.com/submissions 